\title{
Xenotransplantation
}

Official Journal of the International Xenotransplantation Association

\section{Contribution of polymeric materials to progress in xenotransplantation of microencapsulated cells - A review}

\begin{tabular}{|r|l|}
\hline Journal: & Xenotransplantation \\
\hline Manuscript ID & XEN-16-R-0011.R1 \\
\hline Manuscript Type: & Review \\
\hline Complete List of Authors: & $\begin{array}{r}\text { Mahou, Redouan; University of Toronto } \\
\text { Passemard, Solène; Ecole polytechnique federale de Lausanne Faculte des } \\
\text { sciences de base } \\
\text { Carvello, Michele; Ospedale San Raffaele } \\
\text { Petrelli, Alessandra; Ospedale San Raffaele } \\
\text { Noverraz, François; Ecole polytechnique federale de Lausanne Faculte des } \\
\text { sciences de base } \\
\text { Gerber, Sandrine; Ecole polytechnique federale de Lausanne Faculte des } \\
\text { sciences de base } \\
\text { Wandrey, Christine; EPFL, SV-IBI-LMRP }\end{array}$ \\
\hline Keywords: & $\begin{array}{l}\text { Cell microencapsulation, Hydrogels, Permeability, Biocompatibility, } \\
\text { Xenotransplantation }\end{array}$ \\
\hline Topics: & $\begin{array}{l}\text { Cells - Islets, Cells - Other (e.g. neural), Transplantation - small animal } \\
\text { models, Transplantation - large animal/preclinical models, } \\
\text { Immunosuppression }\end{array}$ \\
\hline &
\end{tabular}




\title{
Contribution of polymeric materials to progress in xenotransplantation of microencapsulated cells - A review
}

Redouan Mahou, ${ }^{1,3}$ Solène Passemard, ${ }^{1}$ Michele Carvello, ${ }^{2}$ Alessandra Petrelli, ${ }^{2}$ François Noverraz, ${ }^{1}$ Sandrine Gerber-Lemaire, ${ }^{1 *}$ Christine Wandrey ${ }^{1}$

\author{
${ }^{1}$ Interfaculty Institute of Bioengineering and Institute of Chemical Sciences and Engineering, \\ Ecole Polytechnique Fédérale de Lausanne, Lausanne, Switzerland \\ ${ }^{2}$ Department of Surgery, San Raffaele Scientific Institute, Milan, Italy \\ ${ }^{3}$ Institute for Biomaterials and Biomedical Engineering, University of Toronto, Toronto, Canada
}

Address reprint requests to:

Sandrine Gerber-Lemaire

Institute of Chemical Sciences and Engineering, Ecole Polytechnique Fédérale de Lausanne, EPFL SB ISIC, Batochime, CH-1015 Lausanne, Switzerland. Tel: +41 21693 9372; Fax: +41 21 693 5550; E-mail: sandrine.gerber@epfl.ch 
Abstract: Cell microencapsulation and subsequent transplantation of the microencapsulated cells require multidisciplinary approaches. Physical, chemical, biological, engineering, and medical expertise has to be combined. Several natural and synthetic polymeric materials and different technologies have been reported for the preparation of hydrogels, which are suitable to protect cells by microencapsulation. However, owing to the frequent lack of adequate characterization of the hydrogels and their components as well as incomplete description of the technology, many results of in vitro and in vivo studies appear contradictory or cannot reliably be reproduced. This review addresses the state of the art in cell microencapsulation with special focus on microencapsulated cells intended for xenotransplantation cell therapies. The choice of materials, the design and fabrication of the microspheres, as well as the conditions to be met during the cell microencapsulation process, are summarized and discussed prior to presenting research results of in vitro and in vivo studies. Overall, this review will serve to sensitize medically educated specialists for materials and technological aspects of cell microencapsulation.

Keywords: Cell microencapsulation, hydrogels, mechanical resistance, permeability, biocompatibility, xenotransplantation.

Abbreviations: Alg-CS, alginate-cellulose sulfate; APA, alginate-poly(L-lysine)-alginate capsules; Ca-alg, calcium alginate; cryo-SEM, cryo-scanning electron microscopy; DDA, degree of deacetylation; ECM, extra-cellular matrix; FGF-1, heparin-binding growth factor 1; G, $\alpha$-Lguluronic acid; HPC, hydroxypropyl cellulose; IL, interleukin; ISEC, inverse size-exclusion 2 
chromatography; LCST, lower critical solution temperature; M, D-mannuronic acid; MWCO, molecular weight cut-off; Na-alg, sodium alginate; NICCs, neonatal pig islet-like cell clusters; PEG, poly(ethylene glycol); PLL, poly(L-lysine); PLO, poly(L-ornithine); PMCG, poly(methylene-co-guanidine); PNIPAA, poly(N-isopropylacrylamide); PNVIBA, poly(Nvinylisobutyramide); RGD, arginylglycylaspartic acid; TNF, tumor necrosis factor; UCST, upper critical solution temperature; VEGF, vascular endothelial growth factor; 


\section{Introduction}

Cell-based therapy is an attractive approach to treat several end-stage diseases. The Food and Drug Administration (FDA) defines cell-based therapy as "the prevention, treatment, cure or mitigation of diseases or injuries in humans by the administration of autologous, allogeneic or xenogeneic cells that have been manipulated or altered ex vivo" [1]. While the whole-organ transplantation is limited by the shortage of donors and the need of major surgery, cell-based therapy could overcome both obstacles. Indeed, xenotransplantation will offer an inexhaustible source of cells, and these cells could be delivered near the target site using non-invasive procedures.

In spite of the enormous potential of such approach, progress in the field of cell-based therapy has been hampered for several reasons, in particular due to issues of maintaining cell viability and of the identification of "non-self" cells by the immune system causing transplant rejection. Although better patient and transplant survival rates are achievable by the administration of immunosuppressive treatment, major challenges such as adverse effects associated with these drugs and the risks of long-term immunosuppression are still to be overcome.

The immobilization of cells within a hydrogel material has been identified as efficient strategy to provide mechanical and immune protection to the cells, and to maintain their viability and metabolic functionality for subsequent therapeutic applications [2-3]. Successful applications 
undoubtedly require a multidisciplinary input from materials scientists, chemists, biologists, engineers, and surgeons.

The focus of the present review will be on cell microencapsulation, even though the immobilization and protection of cells is achievable also by other techniques such as immobilization in films, extravascular chambers or in hollow fibers. This review provides an overview of suitable materials under study for cell microencapsulation and discusses the special features of the technologies applied so far. The paper is mainly addressed to medically educated readers working on developing therapies that rely on hydrogels. The selection of suitable material, the design and preparation of spherical hydrogels, as well as the main requirements to be fulfilled during the cell immobilization process are summarized and discussed. Recent trials towards transplantation of xenogeneic microencapsulated cells in order to treat congenital or acquired hormone/enzyme deficiencies as well as degenerative/inflammatory diseases complete this review.

\section{Cell microencapsulation}

Microencapsulation denotes the physical entrapment of a gas, liquid, or solid within a surrounding material with dimensions in the micrometer range. It has gained interest in domains such as agriculture, food, cosmetics, construction, and analytics. Microencapsulation also includes the entrapment of biologically active substances such as cells, tissue, enzymes, bacteria, 5 
or DNA. For such applications, the term bioencapsulation is frequently used. An ambitious challenge in bioencapsulation is cell microencapsulation, which denotes the entrapment of cells while maintaining their viability and metabolic functionality (Figure 1).

Cell immobilization in polymer-based hydrogels was first proposed in 1933 by Bisceglie [4], who demonstrated that insulin-producing cells remained viable and metabolically active after immobilization. Three decades later, Chang proposed the use of semi-permeable membranes as immune-isolating devices, and introduced the term "artificial cells" to define the concept of cell microencapsulation [5]. As shown in Fig. 1, cell microencapsulation offers protection against mechanical stress or deteriorating environmental effects. The surrounding hydrogel allows for bidirectional diffusion of molecules essential for cell metabolism such as oxygen and nutrients, and the release of metabolic products. Simultaneously, the passage of immune cells and antibodies is restricted, giving rise to an immunoprotection for the encapsulated cells. Therapies relying on microencapsulated cells could therefore result in the reduction or even avoidance of the administration of immunosuppressive drugs on the one hand, and on the other hand permit the transplantation of nonhuman cells, which is a promising alternative considering the limited availability of donor organs [6-7]. The therapeutic potential of the transplantation of microencapsulated cells has been reported for the treatment of a variety of diseases, including liver failure [8-10], renal failure [11-13], cancer [14], and diabetes mellitus [15-18].

6 


\section{Hydrogels for cell microencapsulation}

Since the pioneering work of Wichterle on cross-linked poly(hydroxyethyl methacrylate) [19], hydrogels have been of great interest to biomaterial scientists [20-24]. Hydrogels consist of a three-dimensional network of natural [25] or synthetic [26] polymer chains. Due to their high water content, hydrogels have been recognized to meet the requirements for bioencapsulation [27-30]. The cross-linking mechanism determines their classification as physical or chemical hydrogels. Hydrogels are called "physical" or "reversible" if the networks are held together by physical forces only. Chemical hydrogels, also referred to as "permanent", are obtained when polymers having reactive groups link together via covalent bonds. Hydrogels used for cell microencapsulation are hereinafter designated as microspheres, which is a generic name that refers to the size and shape of the materials. According to other classifications of microspheres, which take into account the physical structure of the hydrogel, microspheres are called microbeads if the hydrogel is radially homogeneous. Contrary, the term microcapsule is used if the microsphere is radially heterogeneous, for example, if a microbead was additionally coated with other polymers or if hydrogel surrounds a liquid core.

Physical hydrogels

Physically cross-linked hydrogels possess physical junction domains associated with chain entanglements, ionic or hydrogen bonding, and hydrophobic interactions [31-36]. The interest in 7 
these physical hydrogels is obvious since they are easily obtainable in a one-step process while avoiding the use of cross-linking agents. Only physical hydrogels obtained via ionic bonding or induced by temperature change are discussed herein.

Physical hydrogels by ionic bonding. The principle of preparing physical hydrogels via ionic bonding is schematically represented in Fig. 2. First, when a polyelectrolyte (polymer bearing many positive or negative charges) interacts with multivalent ions of the opposite charge, it may form a physical hydrogel known as "ionotropic" hydrogel. Second, when polyelectrolytes of opposite charges are mixed, they may gel depending on their polymer backbone constitution, concentrations, the ionic strength, as well as the $\mathrm{pH}$ of the solution. The products of such polyanion/polycation interactions are known as complex coacervates, polyelectrolyte complexes, or simplexes. A polyanion was selected in Fig. 2 as example to demonstrate the principle. The complexation of polycations is achievable similarly.

A description of polymers that have been explored in terms of their ability to form physical hydrogels via ionic bonding is presented below.

Sodium alginate. The designation sodium alginate (Na-alg) does not refer to a unique polymer structure but to a variety of polymers, which are composed of the same two monomeric units, $\beta$ D-mannuronic acid (M) and $\alpha$-L-guluronic acid $(\mathrm{G})$, but arranged in different linear sequences 8 
[37, 38]. As shown in Fig. 3, the monomeric units can be arranged as blocks of different lengths or randomly alternated in the polymer chains. Due to the advantageous gelling properties in contact with divalent cations, the Na-alg family is the most frequently used polymeric material for cell microencapsulation. However, the properties of alg-based hydrogels are very sensitive to the nature of the Na-alg and the preparation conditions. Consequently, the knowledge of the molecular and macromolecular characteristics of $\mathrm{Na}$-alg is crucial for the production of defined hydrogels. Fig. 4 summarizes characteristics of Na-alg that influence the properties of alg-based hydrogels.

The chemical composition of Na-alg has an impact on the stability and permeability of the algbased hydrogels [38-40], attributed to ionic bonding between $G$ units and divalent cations, referred to as the egg-box model [41]. The importance of the $\mathrm{G}$ units is highlighted by the fact that the strength of alg-based hydrogels is directly related to the total content of $G$ units and the average length of the $\mathrm{G}$ blocks in Na-alg [42]. Furthermore, it has been demonstrated that calcium alginate beads (Ca-alg) prepared from Na-alg with high $\mathrm{G}$ content are more permeable and exhibit less water uptake compared to $\mathrm{Ca}$-alg prepared from Na-alg with high $\mathrm{M}$ content [43]. The composition-biocompatibility relationship, however, is still a matter of controversy. Some studies reported that Na-alg with a high content of $\mathrm{M}$ evoke an inflammatory response by stimulating monocytes to produce cytokines such as interleukin IL-1, IL-6 and TNF [44]. 9 
Moreover, antibodies were found when high-M alg-based hydrogels were transplanted, but not in the case of high-G alg materials [45]. In contrast, other studies claim high-G alg-based hydrogels to be associated with more severe cell overgrowth [46]. In addition to the composition, the purity of the Na-alg cannot be neglected [47]. There is a consensus that in vitro and in vivo studies have to be conducted using highly purified Na-alg, free of endotoxin, proteins, and polyphenols.

The molar mass of the Na-alg and the concentration of its solution are further important parameters. Na-alg is available with molar mass in the range of 50 to $3000 \mathrm{~kg} / \mathrm{mol}[48,49]$. The viscosity of a Na-alg solution increases with both the molar mass and the concentration of $\mathrm{Na}$ alg. Therefore, a compromise between the molar mass of Na-alg and its concentration is needed to adapt the viscosity of the solution to a specific application in terms of cell type and technology. A selection of applications of Na-alg-based physical hydrogels is listed in Table 1.

In spite of favorable properties, alg-based physical hydrogels suffer from drawbacks such as limited mechanical stability, insufficient durability, and too high permeability. They are dissolved when chelators such as phosphate, lactate, citrate and non-gelling cations are present above a certain concentration [62]. To overcome such problems, subsequent coating of the initially formed hydrogels with polycations to form a polyanion-polycation complex has been proposed. Poly(L-lysine) (PLL), poly(L-ornithine) (PLO), and chitosan are the main polycations that have been suggested for the coating of alg-based hydrogels. A final layer of Na-alg is needed to neutralize the excess of positive charges, to turn the surface charge into negative, and thus to 10 
avoid biocompatibility problems caused primarily by attachment of proteins to a surface with positive charges.

Poly(L-lysine) and poly(L-ornithine). Since the first transplantation of islets of Langerhans microencapsulated in alg-based hydrogel coated with PLL was published [63], the application of PLL as coating material for alg-based hydrogels has been widely reported. Typically, the alginate-poly(L-lysine)-alginate (APA) microcapsule comprises three main components: a core of $\mathrm{Ca}-\mathrm{alg}$ surrounded by an alginate-PLL complex and an outer coating of $\mathrm{Na}$-alg. The coating reinforces the mechanical resistance of $\mathrm{Ca}$-alg and allows for controlling the permeability. The surrounding polyanion-polycation complex reduces the osmotic swelling and thus stabilizes the microcapsule size. Numerous studies using APA to encapsulate cells have been reported [64-70]. Despite improvement of the physical properties of alg hydrogels upon coating with PLL, the immunological response upon transplantation of APA remains a major challenge. A multitude of studies have demonstrated that $\mathrm{Ca}$-alg is better tolerated in vivo than polycation-coated microcapsules [71-73]. The proposed mechanism involves the adhesion of proteins to the surface of the hydrogel when this latter is exposed to blood, plasma or peritoneal fluid. This adhesion initiates the reactive protein cascades and serves as cellular anchor [74-78]. To overcome these biocompatibility issues, different methods have been proposed to reduce the protein adsorption to the surface of APA. For instance, grafting biocompatible poly(ethylene glycol) (PEG) pendent 11 
chains [79-81], optimizing the APA composition [82] and size [83], or using epimerized Na-alg [84] were reported.

Other efforts were directed towards exploring the suitability of other polycations as coating materials. It has been suggested that using PLO has advantages compared to the use of PLL [8587]. PLO is more hydrophilic than PLL due to the difference in the chemical structure, as shown in Fig. 5. PLO binds more efficiently to the surface of Ca-alg, which in turn has a positive impact on the physical properties of the microspheres. Microspheres coated with PLO exhibited higher hydrophilicity, improved mechanical properties, and superior resistance to swelling and damage under osmotic stress $[88,89]$. In terms of biocompatibility, however, the suitability of using PLO instead of PLL is still controversial. Likewise PLL, the immunological response to PLO containing microcapsules was reduced by PEGylation of the outer layer [90]. While some studies claim that promising results are obtained when replacing PLL by PLO [91-93], others suggest that PLL remains the best option $[94,95]$.

Chitosan. Chitosan is a linear polysaccharide consisting of randomly distributed $\beta(1 \rightarrow 4)$ linked D-glucosamine and N-acetyl-D-glucosamine units, as illustrated in Fig. 6. The cationic properties of chitosan depend on the degree of deacetylation (DDA), which is the fraction of glucosamine units. The molar mass depends on the source and isolation procedure, and it can reach values up 12 
to $500 \mathrm{~kg} / \mathrm{mol}$. Lower molar masses and oligomers are obtained by chain degradation [96]. Chitosan is a non-permanently charged cationic polyelectrolyte. Its charge density and solubility strongly depend on the DDA and $\mathrm{pH}$. With a $\mathrm{pK}_{\mathrm{a}}$ value of approximately 6.5 , chitosan is positively charged and soluble in acidic to neutral media, only if the DDA exceeds $60 \%$. Exceptions are oligomers.

Similarly to PLL and PLO, chitosan has been applied to coat Ca-alg or Ba-alg [97]. However, microspheres with a Ca-alg core covered by an alginate-chitosan complex membrane can also be made in a one-stage process by dropping Na-alg into an aqueous solution containing chitosan and calcium ions [98]. The opposite process, dropping chitosan and $\mathrm{Ca}^{2+}$ solutions into Na-alg yields microspheres with a chitosan core and a chitosan-alginate membrane [99]. The stability, permeability, and biocompatibility of alg-chitosan microcapsules were intensely studied [100106]. Several cell types were successfully encapsulated in alg-chitosan microspheres including islets of Langerhans [107, 108], hepatocytes [109-114], and mesenchymal stem cells [115, 116].

Sodium cellulose sulfate and poly(methylene-co-guanidine). Alginate-cellulose sulfatepoly(methylene-co-guanidine) microcapsules (alg-CS/PMCG) are prepared by a two steps process. First, a polyanion blend of $\mathrm{Na}-\mathrm{alg}$ and $\mathrm{CS}$ is gelled in the presence of calcium ions. Second, a membrane is formed via the addition of PMCG. It was demonstrated that both mechanical resistance and permeability of alg-CS/PMCG are tunable by changing the ratio of Na13 
alg/CS in the polyanion blend and the chemical composition [117-119]. A subsequent coating with lower molar mass Na-alg allowed adjusting the permeability over a wide range, suitable for cell microencapsulation and immunoprotection, without compromising the durability of the microspheres. A number of studies using alg-CS/PMCG microcapsules were published [120125]. However, the in vivo biocompatibility remains a major issue. Indeed, when a human whole blood model was used to assess the inflammatory properties of alg-CS/PMCG microspheres, they have triggered complement and leukocyte activation over time, although they were still less activating than PLL-containing microcapsules [71].

Physical hydrogel by temperature-response. The preparation of temperature-responding hydrogels is emerging as a promising tool for various biomedical applications [126], including cell microencapsulation. Such hydrogels are obtained from polymers that respond to temperature change and undergo a sol-gel transition [127, 128]. Derivatives of methylcellulose [129], chitosan [130], hydroxypropyl cellulose (HPC) [131], poly(N-vinylisobutyramide) (PNVIBA) [132], and poly(N-isopropylacrylamide) (PNIPAAm) [133-136] have been reported to exhibit gelation upon temperature change. The latter is a very attractive temperature-responsive polymer since it exhibits a sharp sol-gel transition in water at $34.3^{\circ} \mathrm{C}$. Thus injecting a polymer solution prepared at room temperature (rt) can lead in situ to the formation of hydrogels at $37^{\circ} \mathrm{C}$. 
Moreover, the formation of hydrogels from PNIPAAm is tunable by changing the preparation conditions [137-139].

\section{Chemical hydrogels}

Chemical hydrogels are mostly applied in cell microencapsulation when high mechanical resistance and long-term durability are required. For this purpose, several combinations of polymers and preparation conditions have been tested in regards to their suitability to encapsulate cells within chemical hydrogels. However, only a limited number of combinations have been identified for this purpose. Table 2 lists some examples that have been used to immobilize cells. Numerous criteria must be considered when designing a chemical hydrogel for cell microencapsulation. The process of hydrogel formation must not negatively influence cell integrity and viability and should not involve harsh conditions, toxic solvents and reactants [158]. Because cells are suspended in a liquid precursor solution prior to the encapsulation process, the choice of precursors is limited to water-soluble components. The aqueous solution must be buffered with appropriate osmolality to prevent cell lysis. The rheological properties of the precursor solution are crucial to maintain cell viability and cell-cell adhesion during the encapsulation process. Mixing cells with highly viscous solutions can lead to a significant decrease in cell viability [159].

\section{5}


Hybrid hydrogels

Novel hydrogel types that combine physical and chemical cross-linking, are being emerging as adequate candidates for cell microencapsulation. The physical interactions allow for fast gelation and spherical shape formation, while biocompatible covalent cross-linking ensures the reinforcement of the hydrogel networks, along with tunable permeability and gel stiffness.

For the preparation of APA microspheres with covalent cross-linking between adjacent layers, PLL was equipped with phenyl azide residues that create covalent bonds with Ca-alg when irradiated with UVA [160]. The photo-initiated cross-linking was shown to be cell compatible, and yielded stable microspheres up to 3 years in alkaline buffer ( $\mathrm{pH} 12)$, whereas standard APA disappeared within $1 \mathrm{~min}$. Another strategy reported the replacement of the final alginate layer of APA capsules by poly(methyl vinyl ether-alt-maleic anhydride) (PMM) and poly(vinyl dimethyl azlactone-co-methacrylic acid) (PMV) to form stable covalent amide bonds with PLL, neutralizing the polycation layer [161].

Further, the involvement of methacrylate polymers into physical microspheres, and subsequent covalent cross-linking was reported $[162,163]$. It was demonstrated that either cross-linked shells or cross-linked cores are obtainable by adjusting the molar mass of the cross-linker. Approaches based on chemical cross-linking through complementary reactive groups attached to two oppositely charged polyelectrolytes were also investigated [164, 165]. Similarly, microbeads were prepared by ionotropic gelation of a combination of $\mathrm{Ca}$-alg and sericin as inner core 16 
followed by coating with chitosan and further cross-linking with genipin [166, 167]. This combination effectively reduced swelling and physical disintegration of the microspheres induced by non-gelling ions and calcium chelating agents. Higher resistance to mechanical shear force and improved durability against enzymatic degradation were achieved. The entrapment of vinyl sulfone terminated PEG in Ca-alg and subsequent Michael-type cross-linking has been reported. The mechanical properties of such hybrid microspheres were adjustable and suitable for cell microencapsulation [168-170].

Rather than using hydrogels obtained from oppositely charged polyelectrolytes bearing complementary reactive groups for chemical cross-linking, one-component hybrid hydrogels are also being developed and tested for cell microencapsulation. A one-component system denotes hybrid hydrogels prepared from polymers able to form simultaneously both physical and chemical links. Such polymers are very often a modified macromolecule or biopolymer. For instance, the preparation of hybrid alg-based microspheres was achieved by equipping Na-alg with azide-terminated PEG pendent chains [171]. The azide end group forms chemical crosslinks via the Staudinger reaction by incubation in a gelation bath containing phosphinefunctionalized agents. Human pancreatic islets were encapsulated using such systems [172-174]. Similarly, Na-alg with thiol end groups was prepared $[175,176]$. The modified Na-alg maintained the gelling capacity in the presence of calcium ions, while the thiol end groups ensured the preparation of a chemically cross-linked network via disulfide bond formation. Being 17 
biocompatible, spontaneous, and catalyst free, the formation of disulfide bonds yielded hybrid microspheres in a one-step extrusion process under physiological temperature, $\mathrm{pH}$, and osmolality. Good survival rate and improved proliferation were obtained upon microencapsulation of liver-derived cells within hybrid microspheres [177].

Nonetheless, the strategies described above mainly focused on the robustness of the biomaterials but other parameters must also be underlined. The lifetime and biocompatibility of encapsulated cells should be enhanced to overcome the problem of graft failure [178]. Actually, the survival of engrafted cells depends on the cells adhesion to the hydrogel matrix, on the vascularization improving the delivery of nutrients, oxygen and metabolites but also on the immune response of the host body. For this purpose, hybrid hydrogels containing peptides or proteins were developed. Mimicking the ECM, and the covalent incorporation of adhesives ligands such as galactose [179], RGD [180], and other types of laminin-derived recognition sequences and collagen type I sequence [181] have been reported. Besides these molecules, proteins such as fibrin [182] and collagen [183] but also glycoproteins [184] were also encapsulated to enhance cell viability. Moreover, the co-encapsulation of vascularization promoting factors such as VEGF [185] and FGF-1 [186] promoted the neovascularization by improving the viability of engrafted encapsulated islets. Last but not least, co-encapsulation of anti-inflammatory agents such as complement receptor 1 sCR1 [187], the chemokine CXCL12 [188] or the drug dexamethasone [189] reduced the inflammatory response and thus prolonged the graft survival. Also, anti18 
cytokine agents $[190,191]$ were covalently attached on the hydrogel matrix sequestrating the proinflammatory cytokines highly expressed in wounded environment.

Properties of hydrogel microspheres and their assessment

In addition to the size and size stability as well as chemical stability, the most important characteristics of microspheres, which determine the applicability for subsequent transplantation, are their mechanical resistance, permeability, and biocompatibility. The selection of suitable methods to assess these parameters is not always a straightforward decision.

19 
Mechanical resistance. The mechanical resistance of hydrogel microspheres is not an absolute parameter. It can be evaluated by several methods, each of them providing different information. One method to assess the mechanical resistance is the osmotic pressure test. The microspheres are simply exposed to water [192]. The sudden influx of water causes the microspheres to swell and break. A method to study the resistance to mechanical stress is the microsphere shearing test. A suspension of microspheres is subjected to a controlled fluid shear [193]. The number of broken microspheres as a function of the applied mechanical stress gives an indication of their mechanical resistance. Such essays have the advantage of being very simple. However, they have limitations:

1) only qualitative information, restricted quantification; 2) the osmotic pressure test is reliably applicable only to physical hydrogels. 
Contrary, the evaluation of the resistance and deformability of the microspheres under compression is considered a quantitative method [194]. A mobile probe compresses the microspheres at a defined speed. Microspheres having the same size can be characterized and compared by measuring the force corresponding to the rupture of the microsphere, and by comparing the mechanical resistance at a given degree of compression $[195,196]$. Dependent on the equipment sensitivity and the hydrogel stiffness, two methods are commonly used:

- Each microsphere is individually compressed. The mechanical resistance of 20 to 30 microspheres needs to be analyzed to obtain statistically meaningful data.

- A layer of microspheres is compressed. This method is suitable for capsules that burst at low force. A narrow size distribution is the prerequisite.

Although several methods have been proposed to study the mechanical properties of hydrogels, only few have focused on measuring the mechanical properties of cell-embedding hydrogels. Ahearne et al. reported a non-destructive, online and real-time method that allows measuring the mechanical properties of hydrogels with incorporated cells [197].

\footnotetext{
Permeability. The ability to deliver metabolic products and therapeutic proteins, but to block the diffusion of immune cells and antibodies, is the basis of the use of cell microencapsulation in biomedical applications. A defined and controllable permeability is therefore an essential prerequisite of hydrogel microspheres intended for transplantation. 21
} 
The permeability of microspheres can be described by the mass transfer or diffusion coefficient [198, 199]. It defines the rate of diffusion of a given solute into the hydrogel microsphere. Another quantification is the minimum size of a solute, which is completely excluded from the hydrogel pores. This is usually referred to as the exclusion limit or molecular weight cut-off (MWCO). The determination of solute permeation can be either by diffusion into the microspheres (ingress) or from the microspheres (egress).

Several experimental techniques to assess the permeability of microspheres have been described relying on different solute types and monitoring methods for quantifying the chosen solute. These include, for example, dextrans and pullulans as solutes and spectroscopy (fluorescence, UV/vis), measurement of radioactivity, size exclusion chromatography with concentration-sensitive detectors, and protein assay kits as monitoring methods [200, 201].

An efficient technique that is being used for measuring the permeability is the inverse sizeexclusion chromatography (ISEC) [202, 203]. It has the advantage that the MWCO and its distribution can be determined simultaneously. The drawback is that a minimum of $10 \mathrm{~mL}$ of microspheres is so far needed for each measurement. The optimization of this method to reduce the volume of hydrogel microspheres would be a great achievement.

The hydrogel mesh size, which is the space available between the macromolecular chains, has been also used to describe the permeability of hydrogel microspheres. Direct determination of the mesh size is achieved by cryo-scanning electron microscopy (cryo-SEM), a technique that images 22 
the internal structure of hydrogel microspheres on a nanometer scale [204]. However, the manipulation of the hydrogel during freezing is critical.

Biocompatibility. The assessment of the biocompatibility of hydrogel microspheres is a complex task due to the multitude of interactions between host body and foreign material and because biocompatibility is not simply a property of a material but a property of a biomaterial-host system [205]. Biocompatibility issues of microspheres are often connected with their ability to perform with an "appropriate host response" in a "specific application" [206]. A biocompatible hydrogel is considered to be a system that elicits no or not more than a minimal foreign body reaction. The success of cell microencapsulation intended for transplantation strongly depends on minimizing this immune response. Upon implantation of microencapsulated cells, the immune response is activated by the adsorption of proteins onto the microspheres surface, which will subsequently stimulate the recruitment of immune cells [207], and the rejection of the transplant through one of the many well-documented pathways [208, 209]. The immune response also elicits fibrosis around the hydrogels, which subsequently starves the encapsulated cells by limiting the diffusion of nutrients, and limits the efflux of bioactive molecules secreted from the cells [210]. Thus, most approaches developed to minimize the immune response to hydrogels are focused on preventing protein adsorption and cellular adhesion to the surface of hydrogels through the encapsulation of cells into biologically inert hydrogels, or modification of the hydrogel surface with biocompatible 23 
materials. Very recently, beads size and shape have shown to influence the immune response of the foreign body [211]. It was demonstrated that larger beads $(1.5 \mathrm{~mm})$ reduced immune reactions and fibrosis in comparison to smaller beads $(0.5 \mathrm{~mm})$ when using different materials, including alginate in rats and non-human primate models [212].

In addition to the host reaction, the cell compatibility of the hydrogel is a general biocompatibility prerequisite for a successful therapy using microencapsulated cells. Different cell types could require different hydrogel properties in terms of stiffness or hydrophobicity. In this context, also a minimum of microsphere volume was reported as being advantageous to ensure sufficient oxygen supply and to avoid necrosis [92]. This is in contradiction with results reported in [212].

\section{Cell microencapsulation techniques}

Extrusion techniques

Numerous techniques have been developed for the production of hydrogel microspheres [213, 214]. Most of them are based on forcing the passage of the cell-containing solution through a needle or a nozzle, and its extrusion into a gelation bath. The simplest method comprises dripping with only gravitational force as the driving force. This mode is restricted to low-viscous solutions and yields hydrogel microspheres with diameters in the range of 1.5 to $3 \mathrm{~mm}$. However, the challenge in cell microencapsulation is to produce preferably microspheres with diameters in the 24 
range of 100 to $400 \mu \mathrm{m}$. Indeed, hydrogel microspheres with such dimensions have the advantage of a higher surface-to-volume ratio, exhibiting good transport of nutrients [215]. Subsequently, different processes of droplet formation, which is the first step of cell microencapsulation, are discussed and schematically shown in Fig. 8. A comprehensive database of different encapsulation technologies is available on http://www.genialab.de/WG3/.

Droplet formation by coaxial air-flow. The principle of the coaxial air-flow droplet generator [216] is the use of air-flow to separate droplets from a needle or nozzle tip before they fall due to gravity into a gelling bath. Surface tension gives the droplets their near-spherical shape. Microspheres in the range of $200-1000 \mu \mathrm{m}$ with good uniformity are obtained. However, the size distribution significantly increases for diameters below $400 \mu \mathrm{m}$ [217]. Reasonable production rates are attainable by optimization [218].

Jet breakage by a vibrating nozzle. Small $(<1000 \mu \mathrm{m})$ and uniform $(<3 \%$ size deviation) microspheres can be obtained by employing the jet-break vibrating technique [219]. The technology principle is that a laminar liquid jet breaks up into equally sized droplets by superimposed vibration of the nozzle. However, given that the droplet diameter obtained by this technique is 2 to 3 times larger than the nozzle diameter, the production of capsules with diameters $<400 \mu \mathrm{m}$ needs extrusion nozzles of $150 \mu \mathrm{m}$. Therefore, this technique is not optimal 
for the microencapsulation of large cells or cell clusters. The high mechanical stress to which the cells are exposed might compromise their viability.

Droplet formation by an electrostatic potential. To obtain small uniform droplets, a high electrostatic potential between the needle and the receiving bath can be used [220, 221]. The diameter of the droplets can be tailored by controlling the electrostatic pulses [222-224].

Jet breakage by rotating elements. This technology is especially suitable for the production of large batches of microspheres. Droplets are formed by rotating nozzles, a rotating disk or a cutting wire [225].

Emulsion techniques

Emulsion techniques allow the formation of microspheres with relatively small diameters. The aqueous phase (cell-containing solution) is mixed and dispersed in an organic phase. When the dispersion reaches equilibrium, gel formation is initiated by cooling or by the addition of a gelling agent. Although the emulsion process is advantageous for large-scale production [222226], its use for cell microencapsulation is limited due to the broad size distribution generally obtained. Further, the use of an organic phase and the significant shear stress during emulsion may compromise cell survival [227].

Microfluidic-based cell encapsulation 26 
The recent advances in microfluidics and microlithography provided effective tools to control the formation of hydrogel microspheres with desirable shape, size, and size distribution [228-231]. Microfluidics allow for the preparation of hydrogels with defined morphology such as Janus particles, multi-compartment microspheres and non-spherical microgels [232-239]. Droplets are produced when mixing an aqueous precursor solution with an oil phase such as mineral oil, silicone oil, corn oil, hexadecane or fluorinated oil [240]. The droplets are further internally crosslinked by ionic gelation or by photo-polymerization to obtain cells entrapped in hydrogel microspheres [241]. Obviously, the immiscibility of the two phases is a prerequisite to ensure the formation of spherical droplets [242, 243]. However, the viscosity of the oil has been identified as an important factor controlling the formation of the droplets. The results have shown that highly viscous liquids are emulsified into larger droplets with lower polydispersity [244]. As a proof of concept, several cell types have been encapsulated within hydrogel microspheres using microfluidic droplet formation devices [245-251]. Moreover this technology exhibits ideal solution for single cell encapsulation [252, 253]. The production of a sufficient numbers of droplets in a short-time period remains a major drawback to be overcome. There is therefore a need for scale up studies to adapt this technology for cell microencapsulation [254].

\section{Conformal polymer coating}

\section{7}


If the average diameter of a cell aggregate is considered as $150 \mu \mathrm{m}$, the total volume of a $450 \mu \mathrm{m}$ diameter microcapsule is 27 times larger. This "dead" volume is an often-overlooked issue that can be related to a delayed metabolic response and a slowed diffusion of oxygen and nutrients causing cell necrosis, especially at the center of the microsphere. This issue may also represent a limiting factor if the transplantation of microencapsulated cells is aimed, as only limited space is available at the transplant site. To reduce the microsphere size, depositing a polymer coating directly on the surface of a cell was proposed [255]. As shown in Fig. 9, the total volume equals the size of the cell aggregate plus the thickness of the coating. The advantages from a mass transfer perspective are achieved because of the high ratio of surface to volume. The direct deposit of polymer coatings on the surface of cells has been achieved following different processes such as emulsification [212], discontinuous gradient density centrifugation [256], selective withdrawal [257], or interfacial polymerization [258]. Because of the relatively large cell or cell cluster diameter, conformal polymer coating was preferably applied to islets of Langerhans, using alginate [259], agarose [260], and PEG [261-263] and different chemical strategies were explored to modify covalently the surface of the cells [264]. Polymers such as PLL have been applied for conformal coating after conjugation with biocompatible molecules to attenuate their toxicity [265-267].

\section{Cell microencapsulation for xenotransplantation} 28 
Sites of transplantation

Different surgical sites have been so far used for the transplantation of encapsulated cells [268, 269]. Choosing the surgical site is critical to provide capsules proper intimacy with the outside environment and graft vascularization. In addition to biological functionality, the ideal site for transplantation should be easily accessible for both placement and microcapsule retrieval.

To accomplish these needs, several studies have investigated the peritoneal site. Indeed, the peritoneum is currently considered by several authors a feasible and effective site to implant both encapsulated islets and hepatocytes [270-275]. However, it was also shown that the peritoneal cavity has less chance to provide sufficient oxygen to microencapsulated cells compared to the kidney capsule and muscle [270]. Nonetheless, the peritoneum has shown good results, when used as implantation site for encapsulated cells, despite impaired insulin secretion to glucose stimuli and progressive loss of function in islet transplantation has been reported. Furthermore it has been shown that the capsules are likely to float into the peritoneal cavity with lack of engraftment, clot formation and subsequent poor nutrition. On the other hand, the peritoneum allows the transplantation of large quantity of tissue and further infusions in case of loss of graft function with respect to other sites [276]. In addition, the biocompatibility can be significantly improved by using barium-alginate microcapsules [277]. To overcome low oxygen tension, some authors proposed the construction of an omental pouch providing a more efficient blood supply by capillary neoangiogenesis [278, 279]. Indeed, it was shown that encapsulated islets, 29 
transplanted into the omental pouch, are able to restore euglycemia in NOD mice without immunocytes infiltration around the capsules [279, 280].

The portal vein is traditionally used for human islet transplantation and it is now considered the standard site to make islets exert their function. Moreover closer contact to the vessels should provide efficient nutrition and blood supply. On the other hand the risk of portal vein occlusion and the difficult retrieval of the capsules (harboring both islets and hepatocytes) are important issues to be solved to optimize this site of implantation [281]. Nevertheless, portal puncture during acute liver failure for HT should be balanced as a highly hazardous maneuver due both to coagulopathy and the enhanced risk of occlusion in pathologic liver parenchyma.

Skin and subcutaneous tissue represent the most accessible site for microsphere transplantation regarding surgical implantation and retrieval [282]. Lack of blood supply could be improved by prevascularization of the site [283]. However, para-physiological conditions for the cells to work properly is difficult to obtain in these sites, thus the skin should be used for host-biocompatibility and immunoprotection tests. Vascularization could be improved by using the intramuscular site to maintain good surgical accessibility and graft monitoring.

The kidney capsule has been widely used for murine islet transplantation [284, 285]. It provides good surgical accessibility and retrievability. However, the volume of encapsulated cells required to achieve insulin independence makes this site unconvincing for clinical translation. 
Sources of cells for xenotransplantation

The use of porcine cells for xenotransplantation has been intensively studied, in particular for islet transplantation [286, 287]. Shin et al. demonstrated that adult porcine islets from pathogenfree miniature pigs transplanted into immunosuppressed diabetic monkeys induced fast glucose levels normalization. In addition, normoglycemia was maintained for more than six months in four cases, with no serious advert effects resulting from the transplantation [288]. Several reports highlighted the advantages to use neonatal pig islet-like cell clusters (NICCs) instead of adult pig cells. In particular, NICCs are easily digested and purified, show low level of T-cell response and high resistance to ischemia and inflammation [289]. Optimal functionality was observed after 12 days of culture [290] and tolerance to xenotransplantation of NICCs can be improved by treatment with expanded regulatory $\mathrm{T}$ cells or molecules targeting innate immunity [291]. The ideal age at which these cell clusters should be isolated from porcine donors was established to be during the first month of life, with slight advantages for pigs within the first week of life [292]. Pig-to-monkey islet xenotransplantation was also attempted from adult genetically engineered pigs to overcome the metabolic and immunological barriers between species. However, the multitransgenic islet grafts did not show consistent long-term functionality for several months [293]. The use of pig cells was also investigated in the context of xenotransplantation for the treatment of acute liver-failure [294]. Alginate encapsulated re-aggregated neonatal pig liver cells demonstrated promising efficacy for the treatment of mice with acute liver failure. In addition, 31 
coating of the capsules with chitosan resulted in a reduction of the attachment of macrophages [295]. Recently, No et al reported on the development of a method for the tri-culture of three types of cells from rats to produce uniformly sized and shaped micro liver tissues. Encapsulated in collagen-alginate composites, these cells induced a long-term survival rate of $80 \%$ in mice with $90 \%$ hepatectomy [296]. Other sources of transgenic cells have been investigated. In particular, wide-type and transgenic tilapia donors were considered for the harvesting of islet cells [297, 298]. Transplantation of alginate encapsulated tilapia islets into diabetic mice resulted in long-term (up to 210 days) metabolic control but required immunosuppressive treatment [299]. The significant difference between tilapia insulin and human insulin is nevertheless a strong limitation to clinical application of tilapia islets in cell therapy protocols.

\section{Translation of cell microencapsulation into a xenotransplantation cell therapy}

Since the first reports, in the 1980s, of hydrogel encapsulation of islet- $\beta$-cells for the treatment of type I diabetes mellitus, many studies on animal models addressed the different parameters which can improve biocompatibility, stability and functionality of encapsulated cells. Table 4 lists some of the animal experiments and pre-clinical studies that evaluated the xenotransplantation of encapsulated islets and hepatocytes. 
The encapsulation of different islet types in $\mathrm{Ca}$ - and $\mathrm{Ba}$-alg materials allowed restoring normoglycemia in xenogenic settings, without immunosuppression. Similarly, encapsulated xenogenic hepatocytes were able to revert acute liver failure in rodent models, in absence of immunosuppressive treatment. Despite these encouraging results, the demonstration of effective protocols in patient protocols is still very scarce. In 2011, Calafiore et al reported a phase I clinical trial testing alginate encapsulated islets, transplanted into the portal vein, in 4 type I diabetic patients obtaining transient insulin independence only in one of them, but showing safety, feasibility and biocompatibility of alginate capsules in humans [304]. More recently, Matsumoto et al published the results from a phase I/IIa xenotransplantation study of APA encapsulated neonatal porcine islets in 14 patients with unstable type 1 diabetes [305]. Without immunosuppressive treatment, the transplantation was safe and resulted in the reduction of unaware hypoglycemia events, but did not result in insulin independence.

\section{Concluding remarks, future directions and open questions}

The Holy Grail for transplant investigators is to avoid the use of immunosuppression. Encapsulation of cells and cell clusters could finally lead to this goal by setting up the conditions for long-term function cell therapy without the adverse effect of immunosuppressive agents. Nonetheless, adequate protection of cells from the immune system could expand the field of xenogeneic transplantation. However, despite the recent breakthrough-findings, crucial issues 33 
still remain unsolved. Purity and stability of encapsulation materials should be improved to gain effective biocompatibility [306]. Highly purified alginate-based materials have brought promising results, but capsular overgrowth is still an issue leading to inadequate blood and nutrients supply. Conformal coating of cells and cell clusters seems to be one possibility to overcome problems of cell malnutrition by reducing the distance between cells and capillaries and has shown better quality in terms of immunogenicity. Despite the progress achieved in biotechnology, the balance between immunoprotection and nutrition delivery requires further attention. Interestingly, necrosis of the central region of the encapsulated cells was identified in several studies as the common characteristic for graft failure and thus it was hypothesized that poor nutrition and lack of blood supply are the main causes of loss of function other than failure in immunoprotection [279].

There is no consensus about the ideal site of transplantation. Many reports gave evidence for the advantages of intraperitoneal placement of both encapsulated islets and hepatocytes. Peritoneum is well surgically accessible but the shortage of nutrition impairs the engraftment of encapsulated cells $[307,308]$. Moreover the lack of contact with vessels causes a reduced insulin response to glucose stimuli for the islets. On the other hand, the omental pouch has shown sufficient angiogenesis potential and could be an ideal site for islet transplantation by virtue of direct portal delivery. Intraportal infusion has the advantage of providing more accessible blood supply to the encapsulated cells but it is affected by the risk of occlusion. Hence, optimization of the 34 
microcapsule size is advised in order to avoid unnecessary hydrogel dead-volume. Islet encapsulated therapy has been demonstrated to be effective in the treatment of diabetes in rodent models and large animals. Feasibility and biocompatibility studies in human beings have recently highlighted the potential of this fascinating technology in translational medicine, but effective results in patients are still lacking [309]. However, enough evidence has been gathered to justify clinical trials, in particular for porcine islet xenotransplantation [310]. The other therapeutic area, which might largely benefit from xenotransplantation, is the reversal of acute liver failure. In murine models, the engraftment of encapsulated xenogenic hepatocytes brought new advances in cell therapy $[270,271]$. Xenogeneic sources of hepatocytes should be considered in translational protocols given the shortage of liver donors. Further studies in large animal models are required to prove the effectiveness of this strategy. However, encapsulated hepatocytes have shown, by metabolites de-tossification rate analysis, loss of function within 30 days after transplantation. This short-term cell functionality could be acceptable for therapies intending to provide a bridge for the native liver to regenerate upon acute failure, but is objectionable for a long-term function protocol in order to treat chronic liver diseases. In the near future, cryopreserved microencapsulated cells could be stored in a cell therapy bank with the aim to secure large quantities for patients. Also for this purpose, alginate-based hydrogels were successfully tested. Cryopreservation and re-warming did not negatively affect the function of microencapsulated 
hepatocytes [311, 312]. In conclusion, while the potential of cell microencapsulation for the development of cell therapies has been demonstrated in animal models, long-term studies are still scarcely reported. Despite promising results, translating in particular xenotransplantation of microencapsulated cells into a therapy will require further multidisciplinary efforts. The final success will not least depend on the development of suitable encapsulation materials and technologies. 
References

1. Application of current statutory authorities to human somatic cell therapy products and gene therapy products, notice, Oct 14, 1993 (federal register). (Notice from the center for biologics evaluation and research, center for drug evaluation and research, center for devices and radiological health, U.S. Food and drug administration).

2. Calafiore R, Basta G, Luca G et al. Grafts of microencapsulated pancreatic islet cells for the therapy of diabetes mellitus in non-immunosuppressed animals. Biotechnol Appl Biochem 2004: 39:159-64.

3. Tomaro-Duchesneau C, Saha S, Malhotra M et al. Microencapsulation for the therapeutic delivery of drugs, live mammalian and bacterial cells, and other biopharmaceutics: Current status and future directions. J. Pharm. 2013. Article ID 103527. doi:10.1155/2013/103527

4. Bisceglie VV. Uber die antineoplastische immunität. Krebsforsch 1933: 40: 141-158.

5. Chang TMS. Semipermeable microcapsules. Science 1964: 146: 524-525.

6. Rapport annuel 2012. Fondation Nationale Suisse pour le don et la transplantation d'organes. http://www.swisstransplant.org.

7. Aebischer P. Transplantation in humans of encapsulated xenogeneic cells without immunosuppression: A preliminary report. Transplantation 1994: 58: 1275-1277.

37 
8. Bonavita AG, Quaresma K, Cotta-de-Almeida V et al. Hepatocyte xenotransplantation for treating liver disease. Xenotransplantation 2010: 17: 181-187.

9. Teng Y, Wang Y, Li S et al. Treatment of acute hepatic failure in mice by transplantation of mixed microencapsulation of rat hepatocytes and transgenic human fetal liver stromal cells. Tissue Eng. Part C -meth 2010: 16: 1125-1134.

10. Qiu L, Wang J, Wen X et al. Transplantation of co-microencapsulated hepatocytes and HUVECs for treatment of fulminant hepatic failure. Int. J. Artif. Organs 2012: 35: 458-465.

11. Coussa R, Martoni C, Bhathena J et al. Oral microencapsulated live Saccharomyces cerevisiae cells for use in renal failure uremia: Preparation and in vivo analysis. J. Biomed. Biotechnol. 2010. Article ID 620827. doi:10.1155/2010/620827.

12. Jain P, Shah S, Coussa R, Prakash S. Potentials and limitations of microorganisms as renal failure biotherapeutics. Biologics 2009: 3: 233-243.

13. Brodie JC, Humes HD. Stem cell approaches for the treatment of renal failure. Pharmacol. Rev. 2005: 57: 299-313.

14. Salmons B, Gunzburg WH. Therapeutic application of cell microencapsulation in cancer. Adv Exp Med Biol. 2010: 670: 92-103.

15. Pareta RA. Bioartificial pancreas: Drug delivery through islet microencapsulation to treat diabetes. Recent patents on biomedical engineering 2012: vol 5, issue 1, p41.

38 
16. Basta G, Calafiore R. Immunoisolation of pancreatic islet grafts with no recipient's immunosuppression: Actual and future perspectives. Curr Diab Rep 2011: 11: 384-391.

17. Montanucci P, Pennoni I, Pescara T, Basta G, Calafiore R. Treatment of diabetes mellitus with microencapsulated fetal human liver (FH-B-TPN) engineered cells. Biomaterials 2013: 34: 4002-4012.

18. Dufrane D, Gianello P. Macro- or microencapsulation of pig islets to cure type-1 diabetes. World J Gastroenterol 2012: 18 :6885-6893.

19. Wichterle O, Lim D. Hydrophilic gels for biological use. Nature 1960: 185: 117-118.

20. Hoffman AS. Hydrogels for biomedical applications. Adv Drug Deliver Rev 2002: 54: 3-12.

21. Censi R, Di Martino P, Vermonden T, Hennink WE. Hydrogels for protein delivery in tissue engineering. J Control Release 2012: 161: 680-692.

22. Liu LS, Kost J, Yan F, Spiro RC. Hydrogels from biopolymer hybrid for biomedical, food, and functional food applications. Polymers 2012: 4: 997-1011.

23. Mawad D, Boughton EA, Boughton P, Lauto A. Advances in hydrogels applied to degenerative diseases Curr Pharm Des. 2012: 18: 2558-2575.

24. Seliktar D. Designing cell-compatible hydrogels for biomedical applications. Science 2012: 336: 1124-1128.

25. Gasperini L, Mano JF, Reis RL. Natural polymers for the microencapsulation of cells. J R Soc Interface. 2014: 11: 19 pages.

39 
26. Olabisi RM. Cell microencapsulation with synthetic polymers. J Biomed Mater Res Part A. 2015: 103A: 846-859.

27. Selimović S, Oh J, Bae H, Dokmeci M, Khademhosseini A. Microscale strategies for generating cell-encapsulating hydrogels. Polymers 2012: 4: 1554-1579.

28. Billiet T, Vandenhaute M, Schelfhout J, Van Vlierberghe S, Dubruel P. A review of trends and limitations in hydrogel-rapid prototyping for tissue engineering. Biomaterials 2012: 33 : 6020-6041.

29. Gauvin R, Parenteau-Bareil R, Dokmeci MR, Merryman WD, Khademhosseini A. Hydrogels and microtechnologies for engineering the cellular microenvironment. WIREs Nanomed Nanobiotechnol 2012: 4: 235-246.

30. Borg DJ, Bonifacio E. The use of biomaterials in islet transplantation. Curr Diab Rep. 2011: 11: 434-444.

31. Habibi Y, Lucia LA, Rojas OJ. Cellulose nanocrystals: Chemistry, self-assembly, and applications. Chem. Rev. 2010: 110: 3479-3500.

32. Keerl M, Smirnovas V, Winter R, Richtering W. Interplay between hydrogen bonding and macromolecular architecture leading to unusual phase behavioir in thermosensitive micirogels. Angew. Chem. Int. Ed 2008: 47: 338-341.

33. Wang, H.-J.; Hong, X. Z.; Ba, X.-W. Sol-gel transition in nonlinear hydrogen bonding solutions Macromolecules 2007; 40, 5593-5598;

40 
34. Yilmaz Y. Transition between collapsed state phases and the critical swelling of a hydrogen bonding gel: poly(methacrylic acid-co-dimethyl acrylamide). J Chem Phys 2007: 126: 224501.

35. Schneider HJ, Strongin RM. Supramolecular interactions in chemomechanical polymers. Acc. Chem. Res. 2009: 42: 1489-1500.

36. Das P, Heuser T, Wolf A et al. Tough and catalytically active hybrid biofibers wet-spun from nanochitin hydrogels. Biomacromolecules 2012; 13: 4205-4212.

37. Govan JRW, Fyfe JAM, Jarman TR. Isolation of alginate-producing mutants of pseudomonas fluorescens, pseudomonas putida and pseudomonas mendocina. J. Gen. Microbiol. 1981: 125: 217-220.

38. Fischer FG, Dorfel H. Die polyuronsauren der braunalgen (kohlenhydrate der algen-I). Hoppe-Seylers zeitschrift fur physiologische chemie 1955: 302: 186-203.

39. Mørch YA, Donati I, Strand BL, Skjåk-Braek G. Effect of $\mathrm{Ca}^{2+}, \mathrm{Ba}^{2+}$, and $\mathrm{Sr}^{2+}$ on alginate microbeads. Biomacromolecules 2006: 7: 1471-1480.

40. Moya ML, Morley M, Khanna O, Opara EC, Brey EM. Stability of alginate microbead properties in vitro. J Mater Sci Mater Med 2012: 23: 903-912.

41. Grant GT, Morris ER, Rees DA, Smith PJC, Thom D. Biological interactions between polysaccharides and divalent cations: The egg box model. FEBS Lett. 1973: 32: 195-198.

42. Draget KI, Skjak-Bræek G, Smidsrød O. Alginate based new materials. Int. J. Biol. Macromol. 1997: 21: 47-55.

41 
43. Wandrey C, Espinosa D, Rehor A, Hunkeler D. Influence of alginate characteristics on the properties of multi-component microcapsules. J. Microencapsulation 2003: 20: 597-611.

44. Espevik T, Otterlei M, Skjak-Braek G, Ryan L, Wright SD, Sundan A. The involvement of CD14 in stimulation of cytokine production by uronic acid polymers. Eur. J. Immunol. 1993: 23: 255-261.

45. Kulseng B, Skjåk-Braek G, Ryan L et al. Transplantation of alginate microcapsules: Generation of antibodies against alginates and encapsulated porcine islet-like cell clusters. Transplantation 1999: 67: 978-984.

46. Clayton HA, London NJM, Colloby PS, Bell PRF, James RFL. The effect of capsule composition on the biocompatibility of alginate-poly-l-lysine capsules. J. Microencapsulation 1991: 8: 221-233.

47. Montanucci P, Terenzi S, Santi C, Pennono I, Bini V, Pescara T, Basta G, Calafiore R. Insights in behavior of variably formulated alginate-based microcapsules for cell transplantation. Biomed Res Int. 2015: Article ID 965804: 11 pages.

48. Vauchel P, Arhaliass A, Legrand J, Kaas R, Baron R. Decrease in dynamic viscosity and average molecular weight of alginate from Laminaria digitata during alkaline extraction. Journal of Phycology 2008: 44: 515-517.

49. Mancini M, Moresi M, Sappino F. Rheological behavior of aqueous dispersions of algal sodium alginates. J. Food Eng 1996: 28: 283-295.

42 
50. Du XW, Wu HL, Zhu YF et al. Experimental study of therapy of bone marrow mesenchymal stem cells or muscle-like cells/calcium alginate composite gel for the treatment of stress urinary incontinence. Neurourol urodyn 2013: 32: 281-286.

51. Potentiality of immobilized pig hepatocyte spheroids in bioartificial liver system. Transplant Proc 2012: 44: 1012-1014.

52. Dufrane, D, Van Steenberghe M, Goebbels RM, Saliez A, Guiot Y, Gianello P. The influence of implantation site on the biocompatibility and survival of alginate encapsulated pig islets in rats. Biomaterials 2006: 27: 3201-3208.

53. Moyer HR, Kinney RC, Singh KA et al. Alginate microencapsulation technology for the delivery of adipose-derived stem cells. Ann. Plastic Surg 2010: 65: 497-503.

54. Man Y, Wang P, Guo Y et al. Angiogenic and osteogenic potential of platelet-rich plasma and adipose-derived stem cell laden alginate microspheres. Biomaterials 2012: 33: 8802-8811.

55. Endres M, Wenda N, Woehlecke $\mathrm{H}$ et al. Microencapsulation and chondrogenic differentiation of human mesenchymal progenitor cells from subchondral bone marrow in Caalginate for cell injection. Acta Biomater. 2010: 6: 436-444.

56. Schneider S, Feilen PJ, Brunnenmeier F et al. Long-term graft function of adult rat and human islets encapsulated in novel alginate-based microcapsules after transplantation in immunocompetent diabetic mice. Diabetes 2005: 54: 687-693.

43 
57. Malpique R, Osório LM, Ferreira DS et al. Alginate encapsulation as a novel strategy for the cryopreservation of neurospheres. Tissue Eng Part C Methods 2010: 16: 965-977.

58. Penolazzi L, Tavanti E, Vecchiatini R et al. Encapsulation of Mesenchymal Stem Cells from Wharton's Jelly in Alginate Microbeads. Tissue Eng Part C 2010: 16: 141-155.

59. Qi M, Mørch Y, Lacík I et al. Survival of human islets in microbeads containing high guluronic acid alginate crosslinked with $\mathrm{Ca}^{2+}$ and $\mathrm{Ba}^{2+}$. Xenotransplantation 2012: 19: 355-364.

60. Qi M, Strand BL, Mørch Y et al. Encapsulation of human islets in novel inhomogeneous alginate- $\mathrm{Ca}^{2+} / \mathrm{Ba}^{2+}$ microbeads: In vitro and in vivo function. Artif Cells Blood Substit Immobil Biotechnol 2008: 36: 403-420.

61. Wikström J, Elomaa M, Syväjärvi H et al. Alginate-based microencapsulation of retinal pigment epithelial cell line for cell therapy. Biomaterials 2008: 29: 869-876.

62. Smidsrød, O.; Skjak-Bræk, G. Alginate as immobilization matrix for cells. Trends Biotechnol 1990: 8: 71-78.

63. Lim F, Sun AM. Microencapsulated islets as bioartifical endocrine pancreas. Science 1980: 210: 908-910.

64. Acarregui A, Pedraz JL, Blanco FJ, Hernández RM, Orive G. Hydrogel-based scaffolds for enclosing encapsulated therapeutic cells. Biomacromolecules 2013: 14: 322-330.

65. Huang $\mathrm{X}$, Zhang $\mathrm{X}$, Wang $\mathrm{X}$, Wang $\mathrm{C}$, Tang B. Microenvironment of alginate-based microcapsules for cell culture and tissue engineering. J. Biosci Bioeng 2012: 114: 1-8. 44 
66. Dubrot J, Portero A, Orive G et al. Delivery of immunostimulatory monoclonal antibodies by encapsulated hybridoma cells. Cancer Immunology, immunotherapy 2010: 59: 1621-1631.

67. Santos E, Larzabal L, Calvo A et al. Inactivation of encapsulated cells and their therapeutic effects by means of TGL triple-fusion reporter/biosafety gene. Biomaterials 2013: 34:1442-1451. 68. Santos E, Orive G, Calvo A et al. Optimization of $100 \mu \mathrm{m}$ alginate-poly-1-lysine-alginate capsules for intravitreous administration. J Control Release 2012: 158: 443-450.

69. Shanbhag MS, Lathia JD, Justin D et al. Neural progenitor cells grown on hydrogel surfaces respond to the product of the transgene of encapsulated genetically engineered fibroblasts. Biomacromolecules 2010: 2936-2943.

70. Bhujbal SV, De Haan B, Niclou SP, De Vos P. A novel multilayer immunoisolating encapsulation system overcoming protusion of cells. Sci. Rep. 2014: 4: 6856: 8 pages.

71. Rokstad AM, Brekke OL, Steinkjer B et al. Alginate microbeads are complement compatible, in contrast to polycation containing microcapsules, as revealed in a human whole blood model. Acta Biomater. 2011: 7: 2566-2578.

72. Strand BL, Ryan TL, Kulseng B et al. Poly-L-lysine induces fibrosis on alginate microcapsules via the induction of cytokines. Cell Transplant 2001: 10: 263-275.

73. Juste S, Lessard M, Henley $\mathrm{N}$ et al. Effect of poly-L-lysine coating on macrophage activation by alginate-based microcapsules: Assessment using a new in vitro method. J Biomed Mater Res Part A 2005: 72: 389-398. 45 
74. Nilsson B, Korsgren O, Lambris JD et al. Can cells and biomaterials in therapeutic medicine be shielded from innate immune recognition? Trends Immunol 2010: 31: 32-38.

75. Ekdahl KN, Lambris, JD, Elwing $\mathrm{H}$ et al. Innate immunity activation on biomaterial surfaces: a mechanistic model and coping strategies. Adv Drug Deliv Rev 2010: 63: 1042-1050.

76. Babensee JE, Cornelius RM, Brash JL, Sefton MV. Immunoblot analysis of proteins associated with HEMA-MMA microcapsules: Human serum proteins in vitro and rat proteins following implantation. Biomaterials 1998: 19: 839-849.

77. Tang L, Ugarova TP, Plow EF, Eaton JW. Molecular determinants of acute inflammatory responses to biomaterials. J Clin Invest 1996: 97: 1329-1334.

78. Rokstad AM, Brekke OL, Steinkjer B et al. The induction of cytokines by polycation containing microspheres by a complement dependent mechanism. Biomaterials 2013: 34: 621630.

79. Sawhney AS, Hubbell JA. Poly(ethylene oxide)-graft-poly(L-lysine) copolymers to enhance the biocompatibility of poly(L-lysine)-alginate microcapsule membranes. Biomaterials 1992: 13: $863-870$.

80. Park J-B, Jeong J-H, Lee M, Lee DY, Byun Y. Xenotransplantation of exendin-4 gene transduced pancreatic islets using multi-component (alginate, poly-L-lysine, and polyethylene glycol) microcapsules for the treatment of type 1 diabetes mellitus. J Biomater Sci Polym Ed. 2013: 24: 2045-2057.

46 
81. Spsojevic M, Paredes-Juarez GA, Vorenkamp J, De Haan BJ, Schouten AJ, De Vos P. Reduction of the inflammatory responses against alginate-poly-L-lysine microcapsules by antibiofouling surfaces of PEG-b-PLL diblock copolymers. PLoS ONE. 2014: 9: 11 pages.

82. H A Clayton; Clayton HA, London NJM, Colloby PS et al. The effect of capsule composition on the biocompatibility of alginate-poly-1-lysine capsules. J. Microencapsulation 1991: 8: 221233.

83. Robitaille R, Pariseau JF, Leblond FA et al. Studies on small $(<350 \mu \mathrm{m})$ alginate-poly-Llysine microcapsules. III. Biocompatibility of smaller versus standard microcapsules. J Biomed Mater Res Part A 1999: 44: 116-120.

84. King A, Strand B, Rokstad AM et al. Improvement of the biocompatibility of alginate/polyL-lysine/alginate microcapsules by the use of epimerized alginate as a coating. J Biomed Mater Res Part A 2003: 64: 533-539.

85. Hobbs HA, Kendall WF, Darrabie M et al. Substitution of polyornithine for polylysine in alginate microcapsules. Diabetes 49 (suppl 1): A111.

86. Brunetti P, Basta G, Faloerni A et al. Immunoprotection of pancreatic islet grafts within artificial microcapsules. Int J Artif Organs 1991: 14: 789-791.

87. Calafiore R, Basta G, Boselli C et al. Effects of alginate/polyaminoacidic coherent microcapsule transplantation in adult pigs. Transplant Proc 1997: 29: 2126-2127.

47 
88. Tam SK, Bilodeau S, Dusseault J et al. Biocompatibility and physicochemical characteristics of alginate-polycation microcapsules. Acta Biomater. 2011: 7: 1683-1692.

89 Darrabie MD, Kendall WF, Opara EC. Characteristics of poly-L-ornithine-coated alginate microcapsules. Biomaterials 2005: 26: 6846-6852.

90. Nabavimanesh MM, Hashemi-Najafababi S, Vasheghani-Farahani E. Islets immunoisolation using encapsulation and PEGylation, simultaneously, as a novel design. J Biosci Bioeng. 2015: 119: 486-491.

91. Chen AZ, Bai Y, Wang SB, Liu YG, Chen ZX. Molecular biocompatibility evaluation of poly-L-ornithine-coated alginate microcapsules by investigating mRNA expression of proinflammatory cytokines. J. Biomimetics Biomater. Tissue Eng 2012: 14: 53-64.

92. Calafiore R, Basta G, Luca G et al. Transplantation of pancreatic islets contained in minimal volume microcapsules in diabetic high mammalians. Ann. NY Acad. Sci. 1999: 875: 219-232.

93. Skinner SJM, Geaney MS, Lin H et al. Encapsulated living choroid plexus cells: potential long-term treatments for central nervous system disease and trauma. J. Neural Eng. 2009: 6: art. no. 065001 .

94. Opara EC, Mirmalek-Sani SH, Khanna O, Moya ML, Brey EM. Design of a bioartificial pancreas(+). J. Invest. Med. 2010: 58: 831-837.

95. S J M Skinner. Journal of Neural Engineering Volume 6 Number 6 art. no. 065001

48 
96. Terbojevich M, Muzzarelli RAA R. Chitosan. In: Phillips, G. O. and Williams, P. A. (Eds.). Handbook of Hydrocolloids 2000: 367-378. Cambridge: Woodhead Publishing Ltd.

97. Li S, Zhang Y, Chen L, Li N, Xie H, Guo X, Zhao S, Yu W, Lv Y, Lv G, Wu H, Ma X. The relationship between the inflammatory reponse and cell adhesion on alginate-chitosan-alginate microcapsules after transplantation. J Biomed Mater Res Part A. 2014: 103A: 2333-2343.

98. Huguet ML, Dellacherie E. Calcium alginate beads coated with chitosan: effect of the structure of encapsulated Materials on their release. Process Biochem 1996: 31: 745-751

99. Daly MM, Knorr D. Chitosan-alginate complex coacervate capsules: effects of calcium chloride, plasticizers, and polyelectrolytes on mechanical stability. Biotechnol Prog 1988: 4: 7681.

100. Zhao W, Zhang Y, Liu Y et al. Oxygen diffusivity in alginate/chitosan microcapsules. J. Chem. Technol. Biotechnol. 2012: 88: 449-455.

101. Bartkowiak A, Lisiecki S, Orive G, Pedraz JL. The effect of selected parameters of formation on properties of alginate/ $\mathrm{Ca}^{2+} /$ oligochitosan capsules. J. Chem. Technol. Biotechnol. 2006: 81: 511-518.

102. Baruch L, Machluf M. Alginate-chitosan complex coacervation for cell encapsulation: Effect on mechanical properties and on long-term viability. Biopolymers 2006: 82: 570-579. 103. Orive G, Bartkowiak A, Lisiecki S et al. Biocompatible oligochitosan as cationic modifiers of alginate/Ca microcapsules. J Biomed Mater Res B Appl Biomater. 2005: 74: 429-439. 49 
104. Gåserød O, Smidsrød O, Skjåk-Braek G. Microcapsules of alginate-chitosan-I: A quantitative study of the interaction between alginate and chitosan. Biomaterials 1998: 19: 18151825.

105. Gåserød O, Sannes A, Skjåk-Braek G. Microcapsules of alginate-chitosan-II. A study of capsule stability and permeability. Biomaterials 1999: 20: 773-783.

106. Zheng J, Xie $\mathrm{H}, \mathrm{Yu} \mathrm{W}$ et al. Enhancement of surface graft density of MPEG on alginate/chitosan hydrogel microcapsules for protein repellency. Langmuir 2012: 28: 1326113273.

107. Roshanbinfar K, Salahshour Kordestani S, Encapsulating beta islet cells in alginate, alginate-chitosan and alginate-chitosan-PEG microcapsules and investigation of insulin secretion. Journal of Biomaterials and Tissue Engineering 2013: 3: 185-189.

108. Zhi ZL, Kerby A, King AJ, Jones PM, Pickup JC. Nano-scale encapsulation enhances allograft survival and function of islets transplanted in a mouse model of diabetes. Diabetologia 2012: 55: 1081-1090.

109. Kim SK, Lee JH, Lee DH, Park JK. Optimization of chitosan-alginate encapsulation process using pig hepatocytes for development of bioartificial liver. J. Microbiol. Biotechnol. 2005: 15: 7-13. 
110. Haque T, Chen H, Ouyang W et al. In vitro study of alginate-chitosan microcapsules: An alternative to liver cell transplants for the treatment of liver failure. Biotechnol Lett. 2005: 27: 317-322.

111. Son JH, Ha YM, Kim YI et al. Immobilization of cryopreserved primary rat hepatocytes for the development of a bioartificial liver system. Biotechnol Lett. 2006: 28: 51-54.

112. Seo SJ, Kim IY, Choi YJ, Akaike T, Cho CS. Enhanced liver functions of hepatocytes cocultured with NIH 3 T3 in the alginate/galactosylated chitosan scaffold. Biomaterials 2006: 27: 1487-1495.

113. Chen F, Tian M, Zhang D et al. Preparation and characterization of oxidized alginate covalently cross-linked galactosylated chitosan scaffold for liver tissue engineering. Mater. Sci. Eng., C 2012: 32: 310-320.

114. Lv G, Zhao L, Zhang A et al. Bioartificial liver system based on choanoid fluidized bed bioreactor improve the survival time of fulminant hepatic failure pigs. Biotechnol. Bioeng. 2011: 108: $2229-2236$.

115. Forsey RW, Tare R, Oreffo ROC, Chaudhuri JB. Perfusion bioreactor studies of chondrocyte growth in alginate-chitosan capsules. Biotechnol. Appl. Biochem. 2012: 59: 142152. 
116. Kuo YC, Wang CC. Guided differentiation of induced pluripotent stem cells into neuronal lineage in alginate-chitosan-gelatin hydrogels with surface neuron growth factor. Colloids Surf B Biointerfaces. 2013: 104: 194-199.

117. Renken A, Hunkeler D. Polymethylene-co-guanidine based capsules: A mechanistic study of the formation using alginate and cellulose sulphate. J. Microencapsulation 2007: 24: 20-39.

118. Wandrey C, Espinosa D, Rehor A, Hunkeler D. Influence of alginate characteristics on the properties of multi-component microcapsules. J. Microencapsulation 2003: 20: 597-611.

119. Schuldt U, Hunkeler D. Alginate-cellulose sulphate-oligocation microcapsules: optimization of mass transport and mechanical properties. J Microencapsulation 2007: 24: 1-10.

120. Lacík I, Anilkumar AV, Wang TG. A two-step process for controlling the surface smoothness of polyelectrolyte-based microcapsules. J. Microencapsulation 2001: 18: 479-490.

121. Canaple L, Nurdin N, Angelova N, Hunkeler D, Desvergne B. Development of a coculture model of encapsulated cells. Ann. N.Y. Acad. Sci. 2001: 944: 350-361.

122. Zhang LY, Yao SJ, Guan YX. Diffusion characteristics of solutes with low molecular weight in sodium alginate/cellulose sulfate- $\mathrm{CaCl}_{2} /$ poly(methylene-co-guanidine) capsules. J. Chem. Eng. Data 2003: 48: 864-868.

123. Zhang LY, Yao SJ, Guan YX. Effects of poly(methylene-co-guanidine) on microbial growth in an alginate/cellulose sulphate-CaCl2/poly(methylene-co-guanidine) capsule system. Process Biochem. 2005: 40: 189-193.

52 
124. Nahalka J, Dib I, Nidetzky B. Encapsulation of Trigonopsis variabilis D-amino acid oxidase and fast comparison of the operational stabilities of free and immobilized preparations of the enzyme. Biotechnol Bioeng. 2008: 99: 251-260.

125. Vikartovská A, Bučko M, Mislovičová D et al. Improvement of the stability of glucose oxidase via encapsulation in sodium alginate-cellulose sulfate-poly(methylene-co-guanidine) capsules. Enzyme Microb. Technol. 2007: 41: 748-755.

126. Klouda L, Mikos AG. Thermoresponsive hydrogels in biomedical applications. Eur. J. Pharm. Biopharm. 2008: 68: 34-45.

127. Peppas NA, Bures P, Leobandung W, Ichikawa H. Hydrogels in pharmaceutical formulations. Eur. J. Pharm. Biopharm. 2000: 50: 27.46.

128. Patel A, Mequanint K. Hydrogel Biomaterials. In: Biomedical engineering-Frontiers and challenges, ISBN 979-953-307-028-4, Chapter 14, 275-296, 2011.

129. Stabenfeldt SE, García AJ, LaPlaca MC. Thermoreversible laminin-functionalized hydrogel for neural tissue engineering. J Biomed Mater Res Part A 2006: 77A: 718-725.

130. Zan J, Chen H, Jiang G, Lin Y, Ding F. Preparation and properties of crosslinked chitosan thermosensitive hydrogel for injectable drug delivery systems. J. Appl. Polym. Sci. 2006: 101: 1892-1898.

131. Lu X, Hu Z, Gao J. Synthesis and light scattering study of hydroxypropyl cellulose microgels. Macromolecules 2000: 33: 8698-8702.

53 
132. Kim JH, Lee SB, Kim SJ, Lee YM. Rapid temperature/pH response of porous alginate-gpoly(N-isopropylacrylamide) hydrogels. Polymer 2002: 43: 7549-7558

133. Schmaljohann D. Thermo-responsive polymers and hydrogels in tissue engineering. EPolymers 2005: no. 021

134. Tan H, Ramirez CM, Miljkovic N et al. Thermosensitive injectable hyaluronic acid hydrogel for adipose tissue engineering. Biomaterials 2009: 30: 6844-6853.

135. Suwa K, Wada Y, Kishida A, Akashi M. Synthesis and functionalities of poly(Nvinylalkylamide). VI. A novel thermosensitive hydrogel crosslinked poly(N-vinylisobutyramide). J. Polym. Sci., Part A: Polym. Chem. 1997: 35: 3377-3384.

136. Peroglio M, Grad S, Mortisen D et al. Injectable thermoreversible hyaluronan-based hydrogels for nucleus pulposus cell encapsulation. Eur Spine J. 2012: 21: 839-849.

137. Eeckman F, Amighi K, Moës AJ. Effect of some physiological and non-physiological compounds on the phase transition temperature of thermoresponsive polymers intended for oral controlled-drug delivery. Int J Pharm. 2001: 222: 259-270.

138. Rollason G, Davies JE, Sefton MV. Preliminary report on cell culture on a thermally reversible copolymer. Biomaterials 1993: 14: 153-155.

139. Park TG, Hoffman AS. Estimation of temperature-dependent pore size in poly(Nisopropylacrylamide) hydrogel beads. Biotechnol Prog. 1994: 10: 82-86. 
140. Desai RM, Koshy ST, Hilderband SA, Mooney DJ, Joshi NS. Versatile click alginate hydrogels crosslinked via tetrazine-norbornene chemistry. Biomaterials. 2015: 50: 30-37.

141. Xu K, Fu Y, Chung W. Thiol-ene-based biological/synthetic hybrid biomatrix for 3-D living cell culture. Acta Biomater. 2012: 8: 2504-2516.

142. $\mathrm{Fu} \mathrm{Y}, \mathrm{Xu} \mathrm{K}$, Zheng $\mathrm{X}$ et al. 3D cell entrapment in crosslinked thiolated gelatinpoly(ethylene glycol) diacrylate hydrogels. 2012 Biomaterials 2012: 33: 48-58.

143. Phelps EA, Enemchukwu NO, Fiore VF et al. Maleimide cross-linked bioactive PEG hydrogel exhibits improved reaction kinetics and cross-linking for cell encapsulation and in situ delivery. Adv. Mater. 2012: 24: 64-70.

144. Almany L, Seliktar D. Biosynthetic hydrogel scaffolds made from fibrinogen and polyethylene glycol for 3D cell cultures. Biomaterials 2005: 26: 2467-2477.

145. Cho NJ, Elazar M, Xiong A et al. Viral infection of human progenitor and liver-derived cells encapsulated in 3D PEG-based hydrogel. Biomed. Mater. 2009: 4: 011001

146. Hong Y, Song HQ, Gong YH et al. Covalently crosslinked chitosan hydrogel: Properties of in vitro degradation and chondrocyte encapsulation. Acta Biomater. 2007: 3: 23-31.

147. Hu X, Li D, Gao C. Chemically cross-linked chitosan hydrogel loaded with gelatin for chondrocyte encapsulation. Biotechnol. J. 2011: 6: 1388-1396. 
148. Tan H, Chu CR, Payne KA, Marra KG. Injectable in situ forming biodegradable chitosanhyaluronic acid based hydrogels for cartilage tissue engineering. Biomaterials 2009: 30: 24992506.

149. Brunsen A, Ritz U, Mateescu A et al. Photocrosslinkable dextran hydrogel films as substrates for osteoblast and endothelial cell growth. J. Mater. Chem. 2012: 22: 19590-19604.

150. Liu Y, Chan-Park MB. A biomimetic hydrogel based on methacrylated dextran-graft-lysine and gelatin for 3D smooth muscle cell culture. Biomaterials 2010: 31: 1158-1170.

151. Ferreira LS, Gerecht S, Fuller J et al. Bioactive hydrogel scaffolds for controllable vascular differentiation of human embryonic stem cells. Biomaterials 2007: 28: 2706-2717.

152. Choh SY, Cross D, Wang C. Facile synthesis and characterization of disulfide-cross-linked hyaluronic acid hydrogels for protein delivery and cell encapsulation. Biomacromolecules 2011: 12: 1126-1136

153. Bian L, Hou C, Tous E. The influence of hyaluronic acid hydrogel crosslinking density and macromolecular diffusivity on human MSC chondrogenesis and hypertrophy. Biomaterials 2013: 34: 413-421.

154. Darr A, Calabro A. Synthesis and characterization of tyramine-based hyaluronan hydrogels. J. Mater. Sci. Mater. Med. 2009: 20: 33-44.

155. Flynn L, Prestwich GD, Semple JL, Woodhouse KA. Adipose tissue engineering with naturally derived scaffolds and adipose-derived stem cells. Biomaterials 2007: 28: 3834-3842. 56 
156. Young CJ, Poole-Warren LA, Martens PJ. Combining submerged electrospray and UV photopolymerization for production of synthetic hydrogel microspheres for cell encapsulation. Biotechnol. Bioeng. 2012: 109: 1561-1570.

157. Alves MH, Young CJ, Bozzetto K, Poole-Warren LA, Martens PJ. Degradable, click poly(vinyl alcohol) hydrogels: characterization of degradation and cellular compatibility. Biomed. Mater. 2012: 7: no. 024106

158. Nicodemus GD, Bryant SJ. Cell encapsulation in biodegradable hydrogels for tissue engineering applications. Tissue Eng. Part B 2008: 14: 149-165.

159. Schmidt JJ, Rowley J, Kong HJ. Hydrogels used for cell-based drug delivery. J. Biomed. Mater. Res. A 2008: 87: 1113-1122.

160. Dusseault J, Leblond FA, Robitaille R et al. Microencapsulation of living cells in semipermeable membranes with covalently cross-linked layers. Biomaterials 2005: 26: 1515-1522.

161. Gardner CM, Potter MA, Stöver HDH. Improving covalent cell encapsulation with temporarily reactive polyelectrolytes. J Mater Sci: Mater Med. 2012: 23: 181-193.

162. Mazumder MAJ, Burke NAD, Shen F, Potter MA, Stöver HDH. Core-cross-linked alginate microcapsules for cell encapsulation. Biomacromolecules 2009: 10: 1365-1373.

163. Hillberg AL, Oudshoorn M, Lam JBB, Kathirgamanathan K. Encapsulation of porcine pancreatic islets within an immunoprotective capsule comprising methacrylated glycol chitosan and alginate. J Biomed Mater Res Part B. 2015: 103B: 503-518.

57 
164. Mazumder MAJ, Shen F, Burke NAD, Potter MA, Stöver HDH. Self-crosslinking polyelectrolyte complexes for therapeutic cell encapsulation. Biomacromolecules, 2008: 9: 22922300 .

165. Gardner CM, Stöver HDH. Reactive polyanions based on poly(4,4-dimethyl-2-vinyl-2oxazoline-5-one-co-methacrylic acid). Macromolecules, 2011: 44: 7115-7123.

166. Chen H, Ouyang W, Martoni C. Investigation of genipin cross-linked microcapsule for oral delivery of live bacterial cells and other biotherapeutics: Preparation and in vitro analysis in simulated human gastrointestinal model. Int. J. Polym. Sci 2010: Article ID 985137, doi: $10.1155 / 2010 / 985137$

167. Nayak S, Dey S, Kundu SC. Silk sericin-alginate-chitosan microcapsules: Hepatocytes encapsulation for enhanced cellular functions. Int J Biol Macromol. 2014: 65: 258-266.

168. Mahou R, Wandrey C. Alginate-poly(ethylene glycol) hybrid microspheres with adjustable physical properties. Macromolecules 2010: 43: 1371-1378.

169. Mahou R, Kolláriková G, Gonelle-Gispert C, Meier R, Schmitt F, Tran NM, Dufresne M, Altimari I, Lacík I, Bühler L, Juillerat-Jeanneret L, Legallais C, Wandrey C. Combined electrostatic and covalent polymer networks for cell microencapsulation. Macromol Symp. 2013: 329: 49-57.

170. Mahou R, Meier RPH, Bühler L, Wandrey C. Alginate-poly(ethylene glycol)hybrid microspheres for primary cell microencapsulation. Materials. 2014: 7: 275-286. 58 
171. Gattás-Asfura K, Stabler CL. Chemoselective cross-linking and functionalization of alginate via Staudinger ligation. Biomacromolecules 2009: 10: 3122-3129.

172. Hall KK, Gattás-Asfura K, Stabler CL. Microencapsulation of islets within alginate/poly(ethylene glycol) gels cross-linked via Staudinger ligation. Acta Biomater. 2011: 7: 614-624.

173. Gattás-Asfura K, Fraker CA, Stabler CL. Perfluorinated alginate for cellular encapsulation. J. Biomed. Mater. Res. Part A 2012: 100A: 1963-1971.

174. Gattás-Asfura KM, Valdes M, Celik E, Stabler CL. Covalent layer-by-layer assembly of hyperbranched polymers on alginate microcapsules to impart stability and permselectivity. $\mathrm{J}$ Mater Chem B. 2014: 2: 8208-8219.

175. Mahou R, Wandrey C. Versatile route to synthesize heterobifunctional poly(ethylene glycol) of variable functionality for subsequent pegylation. Polymers 2012: 4: 561-589.

176. Mahou R, Borcard F, Crivelli V, Montanari, E, Passemard S, Noverraz F, Gerber-Lemaire S, Bühler L, Wandrey C. Tuning the properties of hydrogel microspheres by adding chemical cross-linking functionality to sodium alginate. Chem Mater. 2015: 27: 4380-4389.

177. Mahou R, Mai NT, Dufresne, M, Legallais C, Wandrey C. Encapsulation of Huh-7 cells within alginate-poly(ethylene glycol) hybrid microspheres. J. Mater. Sci. Mater. Med. 2012: 23: 171-179. 
178. Lau HK, Kiick KL. Opportunities for multicomponent hybrid hydrogels in biomedical applications. Biomacromol. 2015: 16: 28-42.

179. Tian M, Han B, Tan H, You C. Preparation and characterization of galactosylated alginatechitosan oligomer microcapsule for hepatocytes microencapsulation. Carbohydr Polym. 2014: 112: 502-511.

180. Grigore A, Sarker B, Fabry B, Boccaccini AR, Detsch R. Behavior of encapsulated MG-63 cells in RGD and gelatine-modified alginate hydrogels. Tissue eng. 2014: 20: 2140-2150.

181. Weber LM, Hayda KN, Haskins K, Anseth KS. The effects of cell-matrix interactions on encapsulated $\beta$-cell function within hydrogels functionalized with matrix-derived adhesive peptides. Biomaterials. 2007, 28, 3004-3011.

182. Kim J-S, Lim J-H, Nam H-Y, Lim H-J, Shin J-S, Shin J-Y, Ryu J-H, Kim K, Kwon I-C, Jin S-M, Kim H-R, Kim S-J, Park C-G. In situ application of hydrogel-type fibrin-islet composite optimized for rapid glycemic control by subcutaneous xenogeneic porcine islet transplantation. $\mathrm{J}$ Control Release. 2012: 162: 382-390.

183. Capone SH, Dufresne M, Rechel M, Fleury M-J, Salsac A-V, Paullier P, Daujat-Chavanieu M, Legallais C. Impact of alginate composition: from bead mechanical properties to encapsulated HepG2/C3A cell activities for in vivo implantation. PLoS ONE. 2013: 8: 10 pages.

60 
184. Campanha-Rodrigues AL, Grazioli G, Oliveira TC, Campos-Lisbôa ACV, Mares-Guia TR, Sogayar MC. Therapeutic potential of laminin-biodritin microcapsules for type 1 diabetes mellitus. Cell Transplant. 2015: 24: 247-261.

185. Sigrist S, Mechine-Neuville A, Mandes K, Calenda V, Braun S, Legeay G, Bellocq JP, Pinget M, Kessler L. Influence of VEGF on the Viability of Encapsulated Pancreatic Rat Islets After Transplantation in Diabetic Mice. Cell Transplant. 2002: 12: 627-635.

186. Moya ML,Garfinkel MR, Liu X, Lucas S, Opara C, Greisler HP, Brey EM. Fibrobalst Growth Factor-1 (FGF-1) loaded microbeads enhance local capillary neovascularization. J Surgical Res 2009: 160: 208-212.

187. Luan NM, Iwata H. Xenotransplantation of islets enclosed in agarose microcapsule carrying soluble complement receptor 1. Biomaterials. 2012: 33: 8075-8081.

188. Chen T, Yuan J, Duncanson S, Hibert ML, Kodish BC, Mylavaganam G, Maker M, Li H, Sremac M, Santosuosso M, Forbes B, Kashiwagi S, Cao J, Lei J, Thomas M, Hartono C, Sachs D, Markmann J, Sambanis A, Poznansky

MC. Alginate encapsulant incorporating CXCL12 supports long-term allo and xenoislet transplantation without systemic immune suppression. Am J Tranplant. 2015: 15: 618-627.

189. Acarregui A, Herrán E, Igartua M, Blanco F, Pedraz JL, Orive G, Hermandez RM. Multifunctional hydrogel-based scaffold for improving the functionality of encapsulated therapeutic cells and reducing inflammatory response. Acta Biomater. 2014: 10: 4206-4216. 61 
190. Li C-C, Metters AT, Anseth KS. Functional PEG-peptide hydrogels to modulate local inflammation induced by the proinflammatory cytokine TNFa. Biomaterials. 2009: 30: 49074914.

191. Su J, Hu B-H, Lowe WL, Kaufman DB, Messersmith PB. Anti- imflammatory peptidefunctionalized hydrogels for insulin-secreting cell encapsulation. Biomaterials. 2010: 31: 308314.

192. Thu B, Bruheim P, Espevik T et al. Alginate polycation microcapsules: I. Interaction between alginate and polycation. Biomaterials 1996: 17: 1031-1040.

193. Skarja GA, Kinlough-Rathbone RL, Perry DW, Rubens FD, Brash JL. A coneand- plate device for the investigation of platelet biomaterial interactions. J. Biomed. Mater. Res. 1997: 34: 427-438.

194. Rosiński S, Grigorescu G, Lewińska D et al. Characterization of microcapsules: recommended methods based on round robin testing. J. Microencapsulation 2002:19: 641-659.

195. Drury JL, Dennis RG, Mooney DJ. The tensile properties of alginate hydrogels. Biomaterials 2004: 25: 3187-3199.

196. Jeffrey L, Hinkley A, Morgret LD, Gehrke SH. Tensile properties of two responsive hydrogels. Polymer 2004: 45: 8837-8843.

62 
197. Ahearne M, Yang Y, El Haj AJ, Then KY, Liu KK. Characterizing the viscoelastic properties of thin hydrogel-based constructs for tissue engineering applications. J R Soc Interface 2005: 2: 455-463.

198. Lewińska D, Rosiński S, Hunkeler D, Poncelet D, Weryński A. Mass transfer coefficient in characterization of gel beads and microcapsules. J. Membr. Sci. 2002: 209: 533-540.

199. Li RH, Altreuter DH, Gentile FT. Transport characterization of hydrogel matrices for cell encapsulation. Biotechnol. Bioeng. 1996: 50: 365-373.

200. Schuldt U, Hunkeler D. Characterization methods for microcapsules. Minerva Biotechnologica 2000: 12: 249-264.

201. Uludag H, De Vos P, Tresco PA. Technology of mammalian cell encapsulation. Adv. Drug. Deliv. Rev. 2000: 42: 29-64.

202. Brissova M, Petro M, Lacik I, Powers AC, Wang T. Evaluation of microcapsule permeability via inverse size exclusion chromatography. Anal. Biochem. 1996: 242: 104-111.

203. Brissova M, Lacik I, Powers AC, Anilkumar AV, Wang T. Control and measurement of permeability for design of microcapsule cell delivery system. J. Biomed. Mater. Res. 1997: 39: 61-70.

204. Bertz A, Wöhl-Bruhn S, Miethe S et al. Encapsulation of proteins in hydrogel carrier systems for controlled drug delivery: Influence of network structure and drug size on release rate. J Biotechnol. 2013: 163: 243-249.

63 
205. Williams D. Revisiting the definition of biocompatibility. Med Device Technol. 2003: 14: 10-13.

206. Williams DF. Summary and definitions. In: Progress in biomedical engineering: Definition in biomaterials (4). Elsevier Science Publisher BV; 1987. p. 66-71.

207. Sawhney AS, Hubbell JA. Poly(ethylene oxide)-graft-poly(L-lysine) copolymers to enhance the biocompatibility of poly(L-lysine)alginate microcapsule membranes. Biomaterials 1992: 13: 863-870.

208. Auchincloss H, Sachs DH. Xenogeneic transplantation. Annu. Rev. Immunol. 1998: 16: 433-470.

209. Sayegh MH, Turka LA. The role of T-cell costimulatory activation pathways in transplant rejection. N. Engl. J. Med. 1998: 338: 1813-1821.

210. Kulseng B, Skjåk-Braek G, Ryan L et al. Transplantation of alginate microcapsules: Generation of antibodies against alginates and encapsulated porcine islet-like cell clusters. Transplantation 1999: 67: 978-984.

211. Bhujbal SV, Paredes-Juarez GA, Niclou SP, De Vos P. Factors influencing the mechanical stability of alginate beads applicable for immunoisolation of mammalian cells. J Mech Behav Biomed Mater. 2014: 37: 196-208.

64 
212. Veiseh O, Doloff JC, Ma M, Vegas AJ, Tam HH, Bader AR, Li J, Langan E, Wyckoff J, Loo WS, Jhunjhunwala S, Chiu A, Siebert S, Tang K, Hollister-Lock J, Aresta-Dasilva S, Bochenek M,

Mendoza-Elias J, Wang Y, Qi M, Lavin DM, Chen M, Dholakia N, Thakrar R, Lacík I, Weir GC, Oberholzer J, Greiner DL, Langer R, Anderson

DG. Size- and shape-dependent foreign body immune response to materials implanted in rodents and non-human primates. Nat Mater. 2015: 14: 643-651.

213. Dulieu C, Poncelet, D.; Neufeld, R. J. Ed. W.M. Kühteriber, R. P. Lanza and W. L. Chick. Birkhäuser: Boston (1999): 3-17.

214. Angelova N, Hunkeler D. Rationalizing the design of polymeric biomaterials. Trends. Biotechnol. 1999: 17: 409-421.

215. De Vos P, De Haan B, Pater J, Van Schilfgaarde R. Association between capsule diameter, adequacy of encapsulation, and survival of microencapsulated rat islet allografts. Transplantation 1996: 62: 893-899.

216. Ceausoglu I, Hunkeler D. A new microencapsulation device for controlled membrane and capsule size distributions. J. Microencapsulation 2002: 19: 725-735.

217. Vidal-Serp DS. Polyelectrolytes-based immunoprotection systems: polymer purification and surface analysis. Thesis EPFL N 3053, 2004.

65 
218. Yu J, Wu P-C, Huang C-H, Yang C-Y, Cheng C-M. High-throughput physically based approach for mammalian cell encapsulation. Appl Phys Lett. 2013: 103: 153704.

219. Heinzen C, Marison I, Berger A, von Stockar U. Use of vibration technology for jet breakup for encapsulation of cells, microbes and liquids in monodisperse microcapsules. In

Landbauforschung Voelkenrode, Sonderheft, num. 241 (Practical aspects of encapsulation technologies), p. 19-25, 2002.

220. Hallé JP, Leblond FA, Pariseau JF et al. Studies on small $(<300 \mu \mathrm{m})$ microcapsules II: Parameters governing the production of alginate beads by high voltage electrostatic pulses. Cell Transplant 1994: 3: 365-372.

221. Gryshkov O, Pogozhykh D, Hofmann N, Pogozhykh O, Mueller T, Glasmacher B. Encapsulating non-human primate multipotent stromal cells in alginate via high voltage for cellbased therapies and cryopreservation. PLoS ONE. 2014: 9: 9: e107911: 12 pages.

222. Poncelet D, Babak V, Dulieu C, Picot A. A physico-chemical approach to production of alginate beads by emulsification-internal ionotropic gelation. Colloids Surf. A 1999: 155: 171176.

223. Poncelet D, Neufeld R, Bugarsk B et al. A Parallel plate electrostatic droplet generator: Parameters affecting microbead size. Appl. Microbiol. Biotechnol. 1994: 42: 251-255.

224. Brandenberger H, Widmer F. A new multinozzle encapsulation/immobilization system to produce uniform beads of alginate. J Biotechnol 1998: 63: 73-80.

66 
225. Prüße U, Fox B, Kirchhoff $M$ et al. New process (jet cutting method) for the production of spherical beads from highly viscous polymer solutions. Chem. Eng. Technol. 1998: 21: 29-33.

226. Poncelet D, Lencki R, Beaulieu C et al. Production of alginate beads by emulsification / internal gelation. I. Methodology. Appl. Microbiol. Biotechnol. 1992: 38: 39-45.

227. Rabanel JM, Banquy X, Zouaoui H, Mokhtar M, Hildgen P. Progress technology in microencapsulation methods for cell therapy Biotechnol Prog. 2009: 25: 946-963.

228. Mazzitelli, S., Capretto, L., Quinci, F., Piva, R. \& Nastruzzi, C. Preparation of cellencapsulation devices in confined microenvironment. Advanced Drug Delivery Reviews 2013: 65: $1533-1555$.

229. Kang, A., Park, J., Ju, J., Jeong, G. S. \& Lee, S.-H. Cell encapsulation via microtechnologies. Biomaterials 2014: 35: 2651-2663.

230. Kim, C., Park, J. \& Kang, J. Y. A microfluidic manifold with a single pump system to generate highly mono-disperse alginate beads for cell encapsulation. Biomicrofluidics 2014: 8: 066504.

231. Chau, M. et al. Microfluidic Generation of Composite Biopolymer Microgels with Tunable Compositions and Mechanical Properties. Biomacromolecules 2014: 15: 2419-2425.

232. Wan J, Microfluidic-based synthesis of hydrogel particles for cell microencapsulation and cell-based drug delivery. Polymers 2012: 4: 1084-1108.

67 
233. Seo M, Nie Z, Xu S et al. Continuous microfluidic reactors for polymer particles. Langmuir 2005: 21: 11614-11622.

234. Dendukuri D, Pregibon DC, Collins J, Hatton TA, Doyle PS. Continuous-flow lithography for high-throughput microparticle synthesis. Nat. Mater. 2006: 5: 365-369.

235. Kintses B, Van Vliet LD, Devenish SRA, Holfelder F. Microfluidic droplets: New integrated work-flows for biological experiments. Curr. Opin. Chem. Biol. 2010: 14: 548-555.

236. Khan, I. U. et al. Microfluidic conceived drug loaded Janus particles in side-by-side capillaries device. Int. J. Pharm. 2014: 473: 239-249

237. Mazutis, L., Vasiliauskas, R. \& Weitz, D. A. Microfluidic Production of Alginate Hydrogel Particles for Antibody Encapsulation and Release. Macromol. Biosci. 2015: doi:10.1002/mabi.201500226

238. Utech, S. et al. Microfluidic Generation of Monodisperse, Structurally Homogeneous Alginate Microgels for Cell Encapsulation and 3D Cell Culture. Adv. Healthcare Mater. 2015: 4: 1628-1633.

239. Allazetta, S., Hausherr, T. C. \& Lutolf, M. P. Microfluidic Synthesis of Cell-Type-Specific Artificial Extracellular Matrix Hydrogels. Biomacromolecules 2013: 14: 1122-1131.

240. Luo RC, Chen CH. Structured microgels through microfluidic assembly and their biomedical applications. SciRes Soft 2012: 1: 1-23.

68 
241. Shim TS, Kim SH, Yang SM, Elaborate design strategies toward novel microcarriers for controlled encapsulation and release. Part. Part. Syst. Char. 2013: 30: 9-45.

242. Garstecki P, Fuerstman MJ, Stoen HA, Whiteside GM. Formation of droplets and bubbles in a cicrofluidic T-junction-scaling and mechanism of break-up. Lab Chip 2006: 6: 437-446.

243. Baroud CN, Gallaire F, Dangla R. Dynamics of microfluidic droplets. Lab Chip 2010: 10: 2032-2045.

244. Nie ZH, Seo MS, Xu SQ et al. Emulsification in a microfluidic flow-focusing device: Effect of the viscosities of the liquids. Microfluid Nanofluidics 2008: 5: 585-594.

245. Microfluidic fabrication of self-assembled peptide-polysaccharide microcapsules as 3D environments for Cell Culture 2012;

246. Generation of disk-like hydrogel beads for cell encapsulation and manipulation using a droplet-based microfluidic device 2012;

247. Dalle P, Morales S, Berthier J et al. New microfluidic chip for the production of spherical gelled capsules for cell encapsulation. Technical Proceedings of the 2012 NSTI Nanotechnology Conference and Expo, NSTI-Nanotech 2012: 298-301.

248. Martinez CJ, Kim JW, Ye C et al. A microfluidic approach to encapsulate living cells in uniform alginate hydrogel microparticles. Macromol Biosci. 2012: 12: 946-951.

249. Velasco D, Tumarkin E, Kumacheva E. Microfluidic encapsulation of cells in polymer microgels. Small 2012: 8: 1633-1642.

69 
250. Rossow T, Heyman JA, Ehrlicher AJ et al. Controlled synthesis of cell-laden microgels by radical-free gelation in droplet microfluidics. J Am Chem Soc 2012: 134:4983-4989

251. Headen DM, Aubry G, Lu H, García AJ. Microfluidic-Based Generation of Size-Controlled, Biofunctionalized Synthetic Polymer Microgels for Cell Encapsulation. Adv. Mater. 2014: 26: 3003-3008.

252. Akbari S, Pirbodaghi T. Microfluidic encapsulation of cells in alginate particles via an improved internal gelation approach. Microfluid Nanofluid 2013: 16: 773-777.

253. Wu L, Chen P, Dong Y, Feng X, Liu BF. Encapsulation of single cells on a microfluidic device integrating droplet generation with fluorescence-activated droplet sorting. Biomed Microdevices 2013: 15: 553-560.

254. Tendulkar S, Mirmalek-Sani SH, Childers C et al. A three-dimensional microfluidic approach to scaling up microencapsulation of cells. Biomed Microdevices. 2012: 14: 461-469.

255. Wilson JT, Cui W, Chaikof EL. Layer-by-layer assembly of a conformal nanothin PEG coating for intraportal islet transplantation. Nano Lett. 2008: 8: 1940-1948.

256. Sefton MV, May MH, Lahooti S, Babensee JE. Making microencapsulation work: conformal coating, immobilization gels and in vivo performance J. Controlled Release 2000: 65: 173-186.

257. Wyman JL, Kizilel S, Skarbek R et al. Immunoisolating pancreatic islets by encapsulation with selective withdrawal. Small 2007: 3: 683-690.

70 
258. Cruise GM, Hegre OD, Scharp DS, Hubbell JA. A sensitivity study of the key parameters in the interfacial photopolymerization of poly(ethylene glycol) diacrylate upon porcine islets Biotechnol. Bioeng. 1998: 57: 655-665.

259. Blasi P, Luca G, Mancuso F et al. Conformal polymer coatings for pancreatic islets transplantation. Int. J. Pharm 2013: 440: 141-147.

260. Teramura Y, Iwata H. Bioartificial pancreas: Microencapsulation and conformal coating of islet of Langerhans. Adv. Drug Delivery Rev. 2010: 62: 827-840.

261. Kizilel S, Scavone A, Liu X et al. Encapsulation of pancreatic islets within nano-thin functional polyethylene glycol coatings for enhanced insulin secretion. Tissue Eng. Part A. 2010: 16: $2217-2228$.

262. Luan NM, Teramura Y, Iwata H. Layer-by-layer co-immobilization of soluble complement receptor 1 and heparin on islets. Biomaterials 2011: 32: 6487-6492.

263. Teramura Y, Oommen OP, Olerud J, Hilborn J, Nilsson B. Microencapsulation of cells, including islets, within stable ultra-thin membranes of maleimide-conjugated PEG-lipid with multifunctional crosslinkers. Biomaterials. 2013: 34: 2683-2693.

264. Sorelle JA, Kanak MA, Itoh T, Horton JM, Naziruddin B, Kane RR. Comparison of surface modification chemistries in mouse, porcine, and human islets. J Biomed Mater Res Part A. 2015: 103A: 869-877.

71 
265. Kozlovskaya V, Zavgorodnya O, Kharlampieva E. 2012. Encapsulation and surface engineering of pancreatic islets: Advances and challenges. In Biomedicine, C. Lin (Ed.), Ch.1, pp. 1-32, InTech, (ISBN 978-953-51-0352-3).

266. Wilson JT, Cui W, Kozlovskaya V et al. Cell surface engineering with polyelectrolyte multilayer thin films. J. Am. Chem. Soc. 2011: 133: 7054-7064.

267. Wilson JT, Krishnamurthy VR, Cui W, Qu Z, Chaikof EL. Noncovalent cell surface engineering with cationic graft copolymers. J. Am. Chem. Soc. 2009: 131: 18228-18229.

268. Nöth U, Gröhn P, Jork A et al. 19F-MRI in vivo determination of the partial oxygen pressure in perfluorocarbon-loaded alginate capsules implanted into the peritoneal cavity and different tissues. Magn Reson Med. 1999: 42: 1039-1047.

269. Toso C, Mathe Z, Morel P et al. Effect of microcapsule composition and short-term immunosuppression on intraportal biocompatibility. Cell Transplant. 2005: 14: 159-167.

270. Mai G, Huy NT, Morel P et al. Treatment of fulminant liver failure by transplantation of microencapsulated primary or immortalized xenogeneic hepatocytes. Transplant Proc. 2005: 37: 527-529.

271. Mai G, Huy NT, Morel P et al. Treatment of fulminant liver failure by transplantation of microencapsulated primary or immortalized xenogeneic hepatocytes. Xenotransplantation. 2005: 12: $457-464$. 
272. T, Aomatsu Y, Iwata $\mathrm{H}$ et al. Indefinite islet protection from autoimmune destruction in nonobese diabetic mice by agarose microencapsulation without immunosuppression. Transplantation. 2003: 75: 619-625.

273. Kobayashi T, Arefanian H, Harb G et al. Prolonged survival of microencapsulated neonatal porcine islet xenografts in immune-competent mice without antirejection therapy. Cell Transplant. 2008: 17: 1243-1256.

274. Kobayashi T, Harb G, Rayat GR. Prolonged survival of microencapsulated neonatal porcine islets in mice treated with a combination of anti-CD154 and anti-LFA-1 cmonoclonal antibodies. Transplantation. 2005: 80: 821-827.

275. Cantarelli E, Piemonti L. Alternative transplantation sites for pancreatic islet grafts. Curr Diab Rep. 2011: 11:364-374.

276. Tuch BE, Keogh GW, Williams LJ et al. Safety and viability of microencapsulated human islets transplanted into diabetic humans. Diabetes Care. 2009: 32: 1887-1889.

277. Safley SA, Cui H, Cauffiel S, Tucker-Burden C, Weber CJ. Biocompatibility and immune acceptance of adult porcine islets transplanted intraperitoneally in diabetic NOD mice in calcium alginate poly-L-lysine microcapsules versus barium alginate microcapsules without poly-Llysine. J Diabetes Sci Technol 2008: 2: 760-767.

278. Kin T, Korbutt GS, Rajotte RV. Survival and metabolic function of syngeneic rat islet grafts transplanted in the omental pouch. Am J Transplant. 2003: 3: 281-285. 73 
279. Kobayashi T, Aomatsu Y, Iwata H et al. Survival of microencapsulated islets at 400 days posttransplantation in the omental pouch of NOD mice. Cell Transplant. 2006: 15: 359-365.

280. Kobayashi T, Aomatsu Y, Kanehiro H, Hisanaga M, Nakajima Y. Protection of NOD islet isograft from autoimmune destruction by agarose microencapsulation. Transplant Proc. 2003: 35: 484-485.

281. Fort A, Fort N, Ricordi C, Stabler Cl. Biohybrid devices and encapsulation technologies for engineering a bioartificial pancreas. Cell Transplant. 2008: 17: 997-1003.

282. Veriter S, Mergen J, Goebbels Rm et al. In vivo selection of biocompatible alginates for islet encapsulation and subcutaneous transplantation. Tissue Eng Part A. 2010: 16: 1503-1513.

283. Wang W, Gu Y, Tabata Y et al. Reversal of diabetes in mice by xenotransplantation of a bioartificial pancreas in a prevascularized subcutaneous site. Transplantation. 2002: 73: 122-129. 284. Petrelli A, Carvello M, Vergani A et al. IL-21 is an antitolerogenic cytokine of the latephase alloimmune response. Diabetes. 2011: 60: 3223-3234.

285. Juang JH, Shen CR, Wang JJ et al. Magnetic resonance imaging study of mouse islet allotransplantation. Transplant Proc. 2010: 42: 4217-4220.

286. Cooper DKC, Bottino R, Satyananda V, Wijkstrom M, Trucco M. Toward clinical islet xenotransplantation - are revisions to the IXA guidelines warranted? Xenotransplantation 2013: 20: $68-74$. 
287. Reichart B, Niemann H, Chavakis $\mathrm{T}$ et al. Xenotransplantation of porcine islet cells as a potential option for the treatment of type 1 diabetes in the future. Horm Metab Res 2015: 47: 3135.

288. Shin JS, Kim JM, Kim JS et al. Long-term control of diabetes in immunosuppressed nonhuman primates (NHP) by the transplantation of adult porcine islets. Am J Transplant 2015: 15: $2837-2850$.

289. Zhu H, Yu L, He Y et al. Microencapsulated pig islet xenotransplantation as an alternative treatment of diabetes. Tissue Eng. Part B. 2015: 21: 474-489.

290. Jimenez-Vera E, Davies S, Phillips P et al. Long-term cultured neonatal islet cell clusters demonstrate better outcomes for reversal of diabetes: in vivo and molecular profiles. Xenotransplantation. 2015: 22: 114-123.

291. Van Bürck L, Seissler J. The potential of local immunomodulation and tolerance induction in porcine islet xenotransplantation. Xenostransplantation 2013: 20: 51.

292. Nagaraju S, Bottino R, Wijkstrom M et al. Islet xenotransplantation: what is the optimal age of the islet-source pig? Xenotransplantation 2015: 22: 7-19.

293. Bottino R, Wijkstrom M, van der Windt DJ et al. Pig-to-monkey islet xenotransplantation using multi-transgenic pigs. Am J Transplant. 2014: 14: 2275-2287. 
294. Ramackers W, Klose J, Vondran FWR et al. Species-specific regulation of fibrinogen synthesis with implications for porcine hepatocyte xenotransplantation. Xenotransplantation 2014: $21: 444-453$.

295. Ham DS, Song MS, Park HS et al. Successful xenotransplantation with re-aggregated and encapsulated neonatal pig liver cells for treatment of mice with acute liver failure. Xenotransplantation 2015: 22: 249-259.

296. No DY, Jeong GS, Lee SH. Immune-protected xenogeneic bioartificial livers with liverspecific microarchitecture and hydrogel-encapsulated cells. Biomaterials 2014: 35: 8983-8991.

297. Wright JR Jr, Yang H, Hyrtsenko O et al. A review of piscine islet xenotransplantation using wild-type tilapia donors and the production of transgenic tilapia expressing a "humanized" tilapia insulin. Xenotransplantation 2014: 21: 485-495.

298. White DJ. Fish islet xenografts. Xenotransplantation 2014: 21: 124-126.

299. Safley SA, Cui H, Cauffiel SMD et al. Encapsulated piscine (tilapia) islets for diabetes therapy: studies in diabetic NOD and NOD-SCID mice. Xenotransplantation 2014: 21: 127-139.

300. Schneider S, Feilen PJ, Brunnenmeier F et al. Long-term graft function of adult rat and human islets encapsulated in novel alginate-based microcapsules after transplantation in immunocompetent diabetic mice. Diabetes. 2005: 54: 687-693.

301. Omer A, Duvivier-Kali V, Fernandes J et al. Long-term normoglycemia in rats receiving transplants with encapsulated islets. Transplantation. 2005: 79: 52-58. 76 
302. Gomez N, Balladur P, Calmus Y et al. Evidence for survival and metabolic activity of encapsulated xenogeneic hepatocytes transplanted without immunosuppression in Gunn rats. Transplantation. 1997: 63: 1718-1723.

303. Kin T, Korbutt GS, Rajotte RV. Normalization of diabetes in spontaneously diabetic cynomologus monkeys by xenografts of microencapsulated porcine islets without immunosuppression. J Clin Invest. 1996: 98: 1417-1422.

304. Basta G, Montanucci P, Luca G et al. Long-term metabolic and immunological follow-up of nonimmunosuppressed patients with type 1 diabetes treated with microencapsulated islet allografts: four cases. Diabetes Care. 2011: 34: 2406-2409.

305. Matsumoto S, Tan P, Baker J, Durbin K, Tomiya M, Azuma K, Doi M, Eliott RB. Clinical porcine islet xenotransplantation under comprehensive regulation. Transplant Proc. 2014: 46: 1992-1995.

306. Ludwig B, Ludwig S. Transplantable bioartificial pancreas devices: current status and future prospects. Langenbecks Arch Surg. 2015: 400: 531-540.

307. De Vos P, Van Straaten JF, Nieuwenhuizen AG et al. Why do microencapsulated islet grafts fail in the absence of fibrotic overgrowth? Diabetes. 1999: 48: 1381-1388.

308. De Vos P, Vegter D, Strubbe JH, De Haan BJ, Van Schilfgaarde R. Impaired glucose tolerance in recipients of an intraperitoneally implanted microencapsulated islet allograft is 
caused by the slow diffusion of insulin through the peritoneal membrane. Transplant Proc. 1997: 29: 756-757.

309. Cooper DKC. The case for xenotransplantation. Clin Transplant. 2015: 29: 288-293.

310. Ellis CE, Korbutt GS. Justifying clinical trials for porcine islet xenotransplantation. Xenotransplantation 2015: 22: 336-344.

311. Agudelo CA, Teramura Y, Iwata H. Cryopreserved agarose-encapsulated islets as bioartificial pancreas: a feasibility study. Transplantation. 2009: 87: 29-34.

312. Schneider S, Klein HH. Long-term graft function of cryostored alginate encapsulated rat islets. Eur J Med Res. 2011: 16: 396-400. 
Table 1. Selected alg-based physical hydrogels applied for cell microencapsulation

\begin{tabular}{|c|c|c|c|}
\hline $\begin{array}{c}\text { Divalent } \\
\text { ions }\end{array}$ & Cell type & Target & Reference \\
\hline $\mathrm{Ca}^{2+}$ & $\begin{array}{l}\text { BMSC }^{1} \\
\text { Hepatocytes } \\
\text { Pig islets } \\
\text { ADSC }^{2} \\
\text { CSP }^{3}\end{array}$ & $\begin{array}{l}\text { Treatment of stress urinary incontinence } \\
\text { Development of bio-artificial liver } \\
\text { Impact of implantation sites on the biocompatibility } \\
\text { Study of angiogenic and osteogenic potential of ADSC } \\
\text { Therapeutic approach for cartilage regeneration }\end{array}$ & $\begin{array}{c}{[50]} \\
{[51]} \\
{[52]} \\
{[53,54]} \\
{[55]}\end{array}$ \\
\hline $\mathrm{Ba}^{2+}$ & $\begin{array}{l}\text { Rat islets } \\
\text { Neuroblastoma } \\
\text { WJMSC }^{4}\end{array}$ & $\begin{array}{l}\text { Study of islets function in vitro and in vivo } \\
\text { Cryopreservation of neurospheres by encapsulation } \\
\text { Optimized microencapsulation of MSC by vibrational nozzle }\end{array}$ & $\begin{array}{l}{[56]} \\
{[57]} \\
{[58]}\end{array}$ \\
\hline $\mathrm{Ba}^{2+} / \mathrm{Ca}^{2+}$ & $\begin{array}{l}\text { Human islets } \\
\text { ARPE- } 19^{5}\end{array}$ & $\begin{array}{l}\text { Viability and function after transplantation into diabetic mice. } \\
\text { In vitro study of encapsulated human retinal pigment epithelial cells }\end{array}$ & $\begin{array}{c}{[59,60]} \\
{[61]}\end{array}$ \\
\hline
\end{tabular}


Table 2. Examples of chemical hydrogels applied for cell immobilization

\begin{tabular}{|c|c|c|c|}
\hline Material & Preparation & Cell & Reference \\
\hline Alginate & $\begin{array}{l}\text { Click reaction with tetrazine-norbornene modified hydrogel } \\
\text { (no ionic cross-linkings) }\end{array}$ & $\begin{array}{l}\text { EGFP-expressing } 3 \mathrm{~T} 3 \\
\text { fibroblast }\end{array}$ & {$[140]$} \\
\hline \multirow{4}{*}{ PEG } & Thiol-ene reaction of PEG diacrylate with thiolated gelatin & Fibroblasts; keratinocytes & {$[141,142]$} \\
\hline & $\begin{array}{l}\text { Maleimide, acrylate and vinyl sulfone-modified PEG cross- } \\
\text { linked with peptides }\end{array}$ & $\mathrm{C} 2 \mathrm{C} 12$ myoblast & [143] \\
\hline & $\begin{array}{l}\text { Photo-polymerization of fibrinogen-g-PEGacryloyl and PEG } \\
\text { diacrylate }\end{array}$ & BMSC & [144] \\
\hline & Photo-polymerization of PEG diacrylate & Huh-7.5 & [145] \\
\hline \multirow{3}{*}{ Chitosan } & $\begin{array}{l}\text { Photo-polymerization of chitosan grafted with lactic acid and } \\
\text { methacrylate }\end{array}$ & \multirow{3}{*}{ Chondrocytes } & [146] \\
\hline & Chemically cross-linked chitosan hydrogel loaded with gelatin & & [147] \\
\hline & N-succinyl-chitosan gelation with aldehyde hyaluronic acid & & [148] \\
\hline \multirow{3}{*}{ Dextran } & Photo-polymerization of dextran with benzophenone & Osteoblast-endothelial cell & [149] \\
\hline & Gelation of methacrylate and lysine functionalized dextran & Smooth muscle cells & [150] \\
\hline & Photopolymerization of dextran-acrylate & Embryonic stem cells & [151] \\
\hline \multirow{4}{*}{ HA } & HA cross-linked via disulfide bond formation reaction & Fibroblasts, stem cells & [152] \\
\hline & Methacrylated HA cross-linked by UV exposure & MSC & [153] \\
\hline & Peroxidase catalyzed oxidation of tyramine-substituted HA & Chondrocytes & [154] \\
\hline & Conjugate addition of thiol-modified HA onto PEG diacrylate & Adipocyte-stem cells & [155] \\
\hline \multirow{2}{*}{ PVA } & UV photopolymerization & \multirow{2}{*}{ L929 fibroblast } & [156] \\
\hline & Click hydrogels formed by hydrazone bonds & & {$[157]$} \\
\hline
\end{tabular}


Table 3. Xenotransplantation of encapsulated cells in animal models

\begin{tabular}{|c|c|c|c|c|}
\hline $\begin{array}{c}\text { Transplanted } \\
\text { model }\end{array}$ & Cell type & Transplantation site & $\begin{array}{l}\text { Materials for } \\
\text { encapsulation }\end{array}$ & Reference \\
\hline \multirow{6}{*}{ Mice } & Neonatal porcine islets & Peritoneal cavity & Ca-alg and Ba-alg & $\begin{array}{l}{[273]} \\
{[274]}\end{array}$ \\
\hline & Rat islets & $\begin{array}{l}\text { Subcutaneous tissue } \\
\text { Intraperitoneal space } \\
\text { Peritoneal cavity }\end{array}$ & $\begin{array}{l}\text { Agarose / poly (styrene } \\
\text { sulfonic acid) } \\
\text { Alg-PLL-PEG } \\
\text { Agarose }\end{array}$ & $\begin{array}{l}{[283]} \\
{[80]} \\
{[187]}\end{array}$ \\
\hline & Human islets & $\begin{array}{l}\text { Omental pouch } \\
\text { Peritoneal cavity }\end{array}$ & $\begin{array}{l}\text { Agarose } \\
\text { Ba-alg } \\
\end{array}$ & $\begin{array}{l}{[279]} \\
{[300]}\end{array}$ \\
\hline & Neonatal pig hepatocytes & Abdominal cavity & Ba-alg & [295] \\
\hline & \begin{tabular}{|l} 
Rat hepatocytes \\
Human hepatocytes \\
\end{tabular} & Peritoneal cavity & Alg-PLL-alg & {$[270,271]$} \\
\hline & Fish islets & Abdominal cavity & Ba-alg & [299] \\
\hline \multirow[b]{2}{*}{ Rat } & Pig islets & $\begin{array}{l}\text { Subcutaneous tissue } \\
\text { Abdominal cavity }\end{array}$ & $\begin{array}{l}\text { Ca-alg } \\
\text { Ba-alg }\end{array}$ & $\begin{array}{l}{[282]} \\
{[301]}\end{array}$ \\
\hline & Guinea pig hepatocytes & Peritoneal cavity & $\begin{array}{l}\text { acrylonitrile-sodium } \\
\text { methallyl-sulfonate } \\
\text { copolymer }\end{array}$ & {$[302]$} \\
\hline \multirow{2}{*}{$\begin{array}{l}\text { Non human } \\
\text { primates }\end{array}$} & \multirow{2}{*}{ Pig islets } & Intraportal injection & No material & $\begin{array}{l}{[288]} \\
{[293]}\end{array}$ \\
\hline & & Intraperitoneal space & Ca-alg-PLL & [303] \\
\hline
\end{tabular}

81 


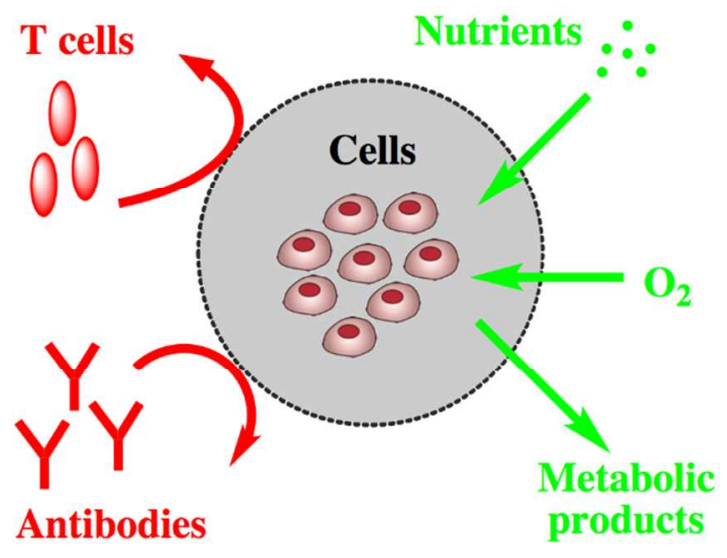

Fig. 1. Schematic representation of cell microencapsulation. 


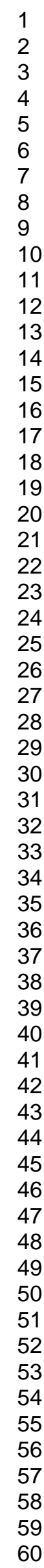

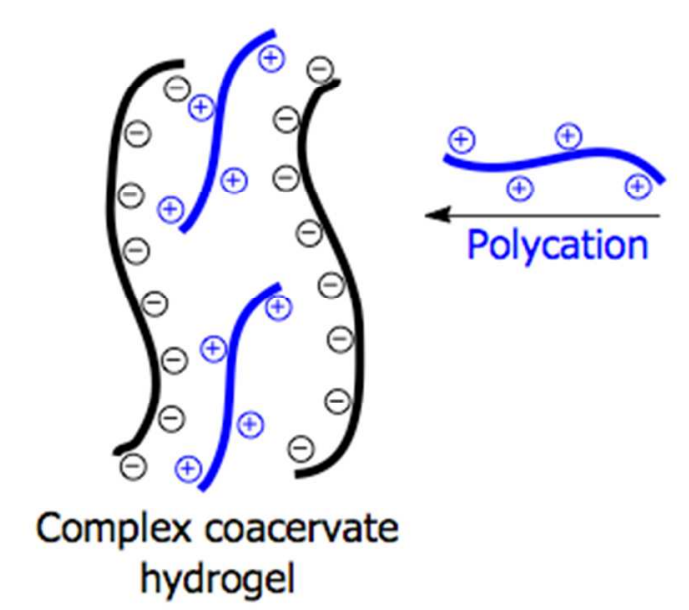

Polyanions

Fig. 2. Principles to form physical hydrogels by ionic bonding. 


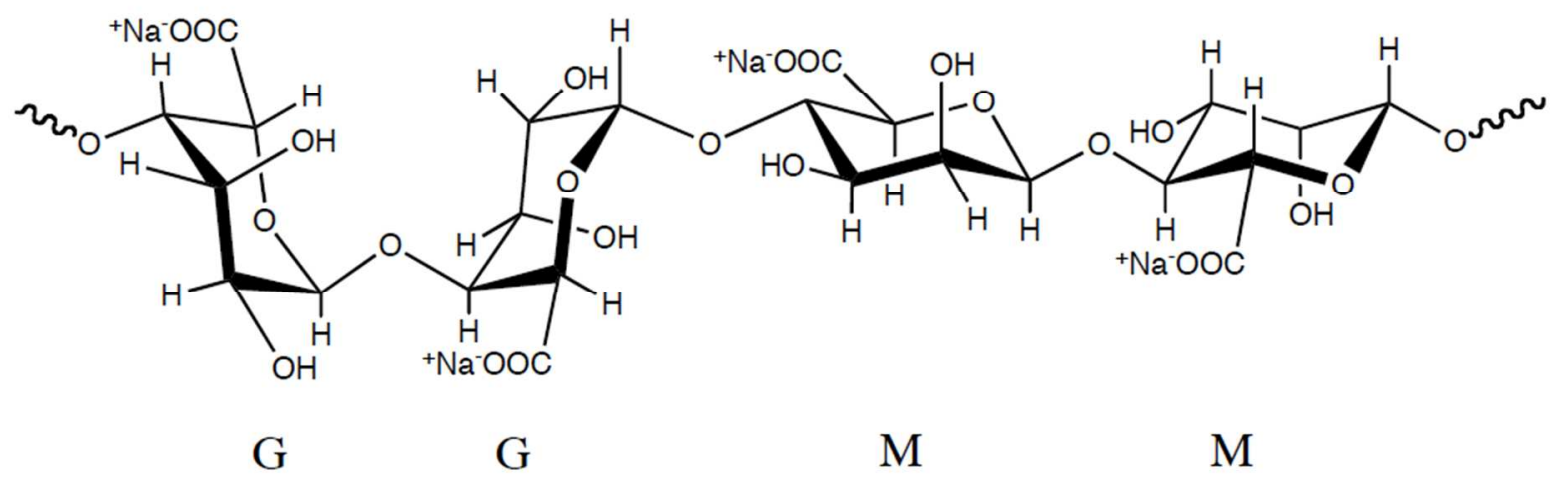

Fig. 3. Na-alg consists of $\alpha$-L-guluronic and $\beta$-D-manuronic acid residues.

\section{4}


Fig. 4. The properties of alg-based hydrogels depend on the nature of the applied Na-alg, (solid line) confirmed influence, (dotted line) controversially discussed. 


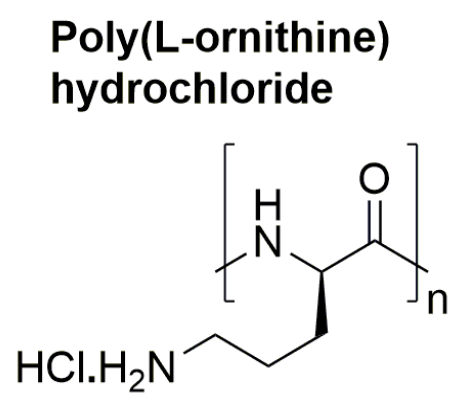

Fig. 5. Chemical structure of poly(L-lysine) hydrochloride and poly(L-ornithine) hydrochloride. 
1

2

3

4

5

6

7

8

9

10

11

12

13

14

15

16

17

18

19

20

21

22

23

24

25

26

27

28

29

30

31

32

33

34

35

36

37

38

39

40

41

42

43

44

45

46

47

48

49

50

51

52

53

54

55

56

57

58

59

60

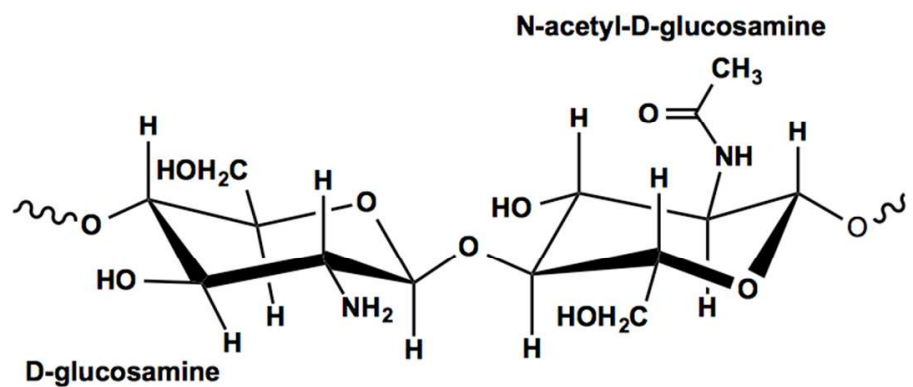

Fig. 6. The chemical structure of chitosan. 


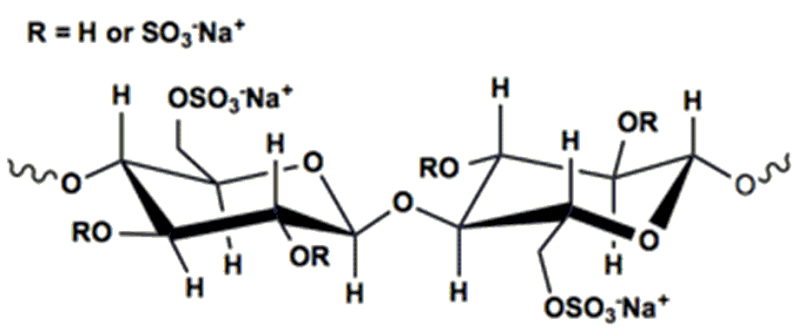

Sodium Cellulose Sulfate

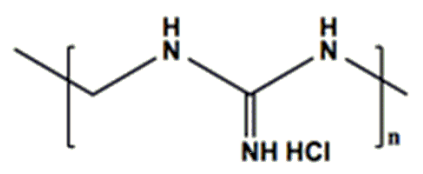

Poly(methylene-co-guanidine)

Fig. 7. The chemical structures of sodium cellulose sulfate (CS) and poly(methylene-coguanidine) hydrochloride (PMCG).

\section{8}


1

2

3

4

5

6

7

8

9

10

11

12

13

14

15

16

17

18

19

20

21

22

23

24

25

26

27

28

29

30

31

32

33

34

35

36

37

38

39

40

41

42

43

44

45

46

47

48

49

50

51

52

53

54

55

56

57

58

59

60
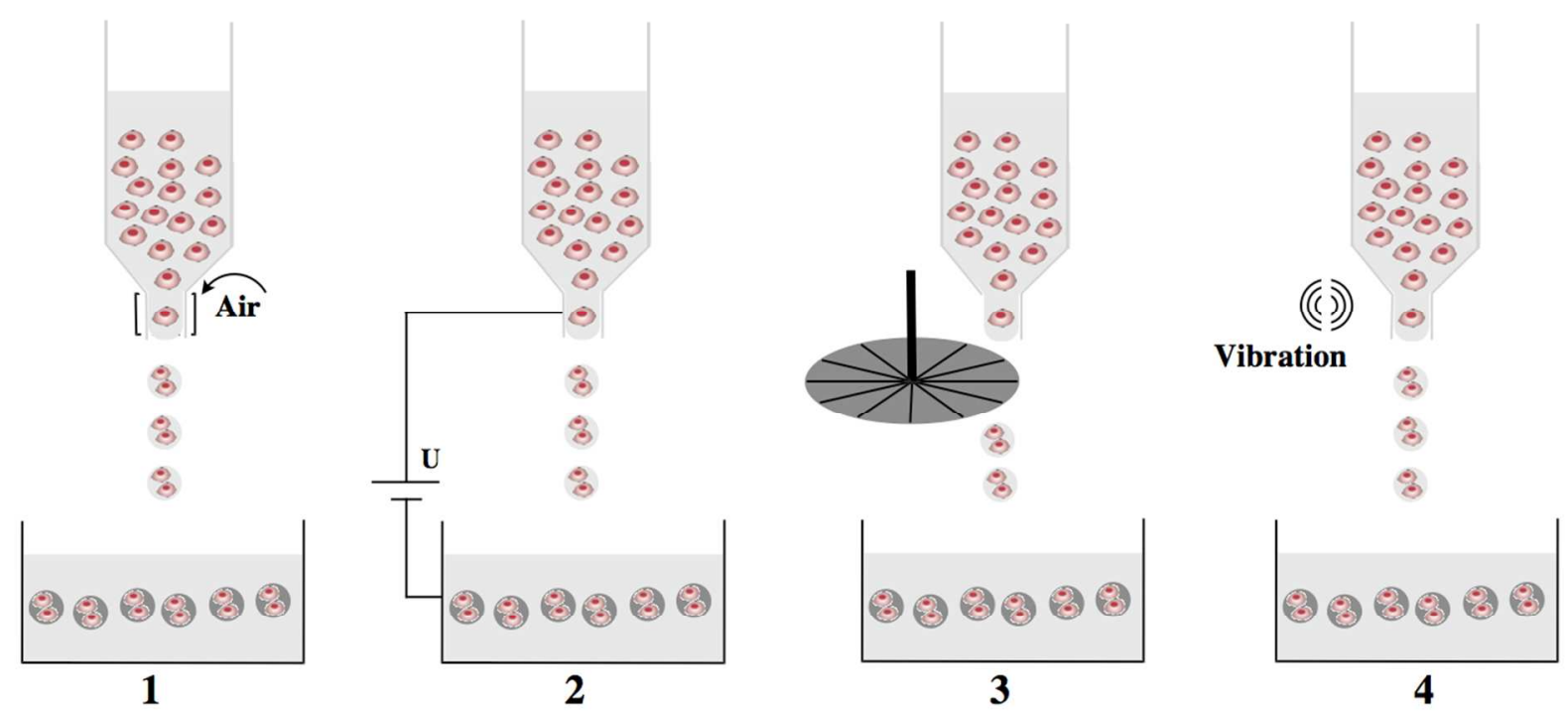

Fig. 8. Formation of droplets by: coaxial air-flow (1), electrostatic potential (2), rotating disk (jet cutter) (3), and vibrating nozzle (4). Cells are finally entrapped in hydrogel microspheres after falling down in the gelation bath.

89 


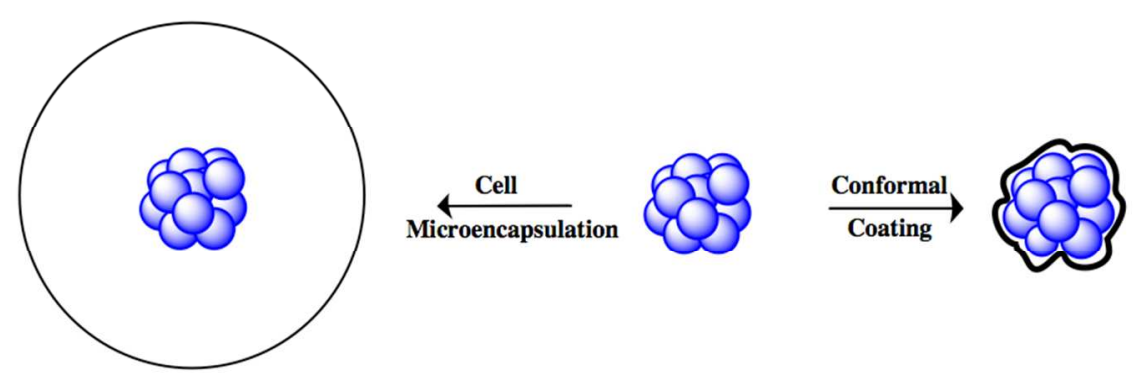

Fig. 9. Comparison of conformal coating and cell microencapsulation. 


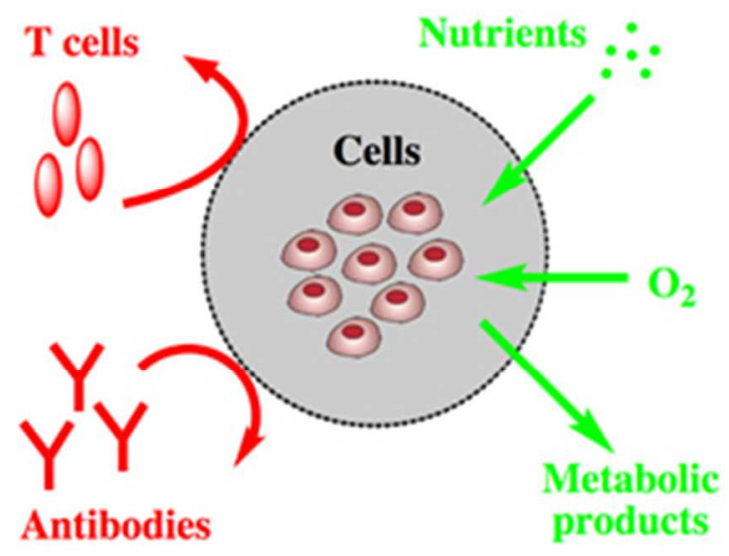

Figure 1. Schematic representation of cell microencapsulation $95 \times 73 \mathrm{~mm}(72 \times 72$ DPI $)$ 


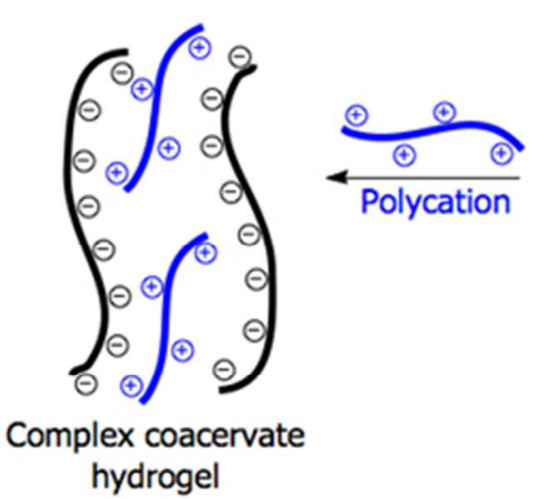

Polyanions

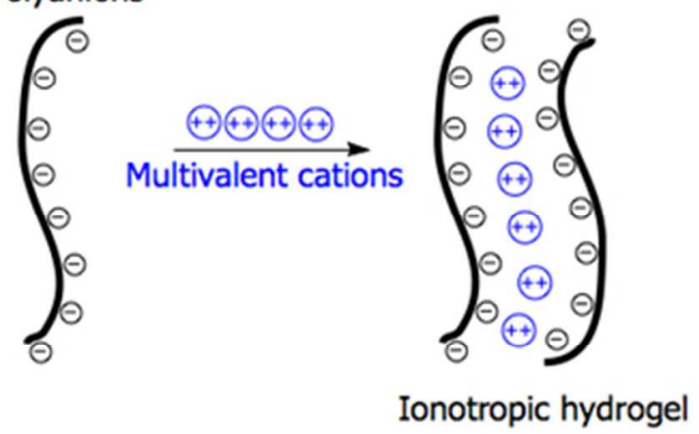

Figure 2. Principles to form physical hydrogels by ionic bonding $214 \times 85 \mathrm{~mm}(72 \times 72$ DPI $)$ 


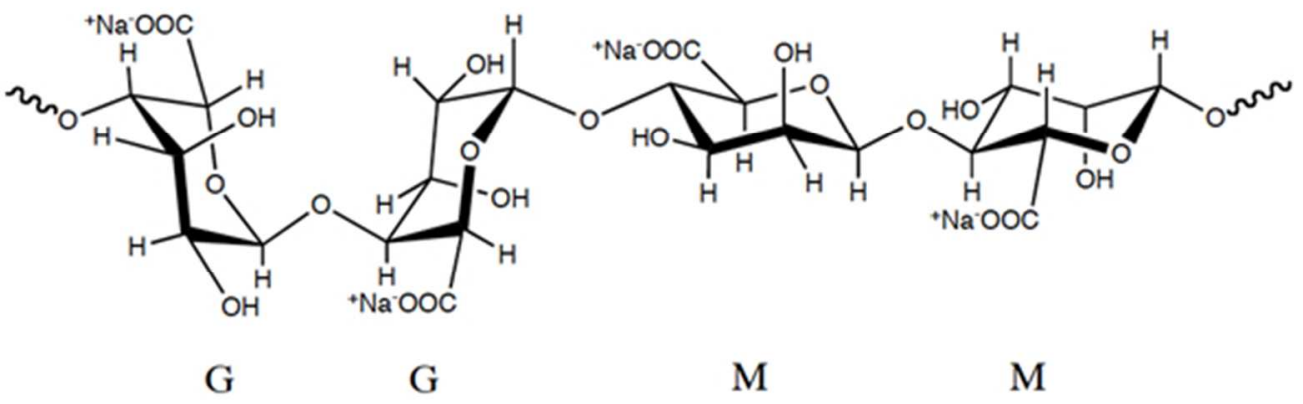

Figure 3. Na-alg consists of a-L-guluronic and $\beta$-D-manuronic acid residues $209 \times 67 \mathrm{~mm}(72 \times 72$ DPI $)$ 
Figure 4. The properties of alg-based hydrogels depend on the nature of the applied Na-alg, (solid line) confirmed influence, (dotted line) controversially discussed $168 \times 74 \mathrm{~mm}(72 \times 72$ DPI $)$ 


\section{Poly(L-lysine) hydrochloride}

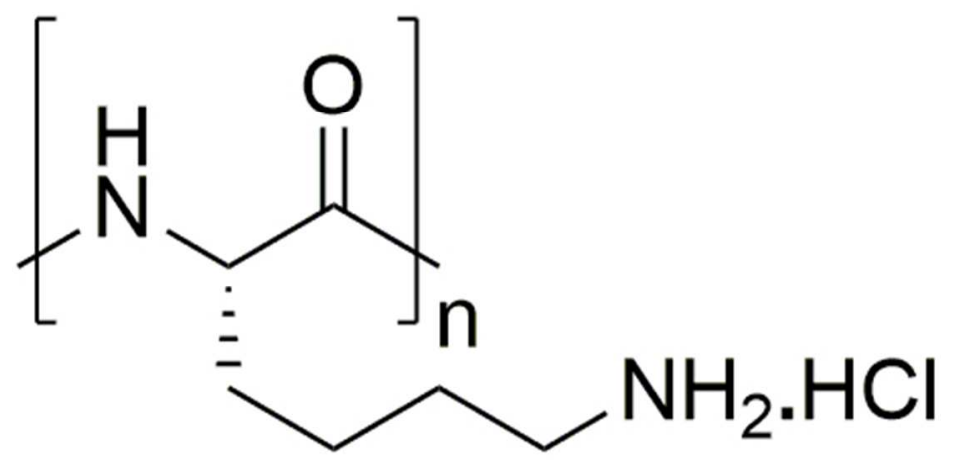

\section{Poly(L-ornithine) hydrochloride}

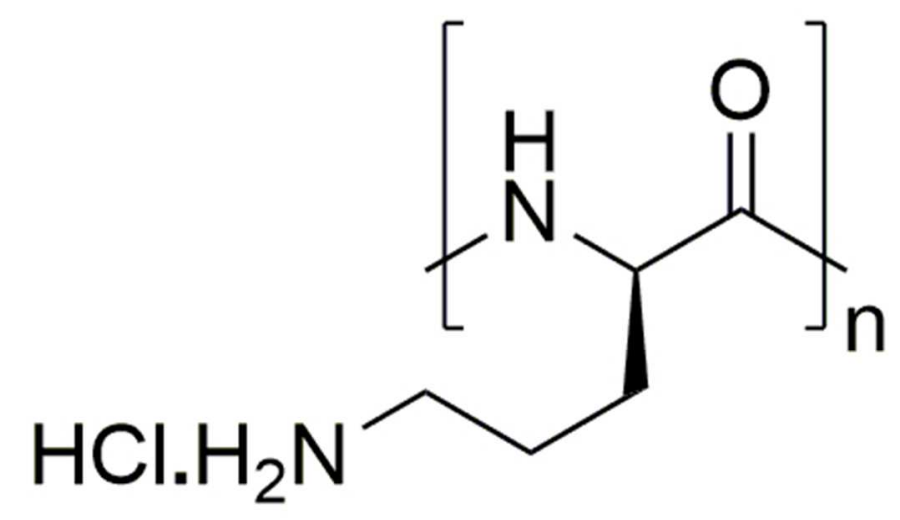

Figure 5. Chemical structure of poly(L-lysine) hydrochloride and poly(L-ornithine) hydrochloride $40 \times 65 \mathrm{~mm}(300 \times 300 \mathrm{DPI})$ 


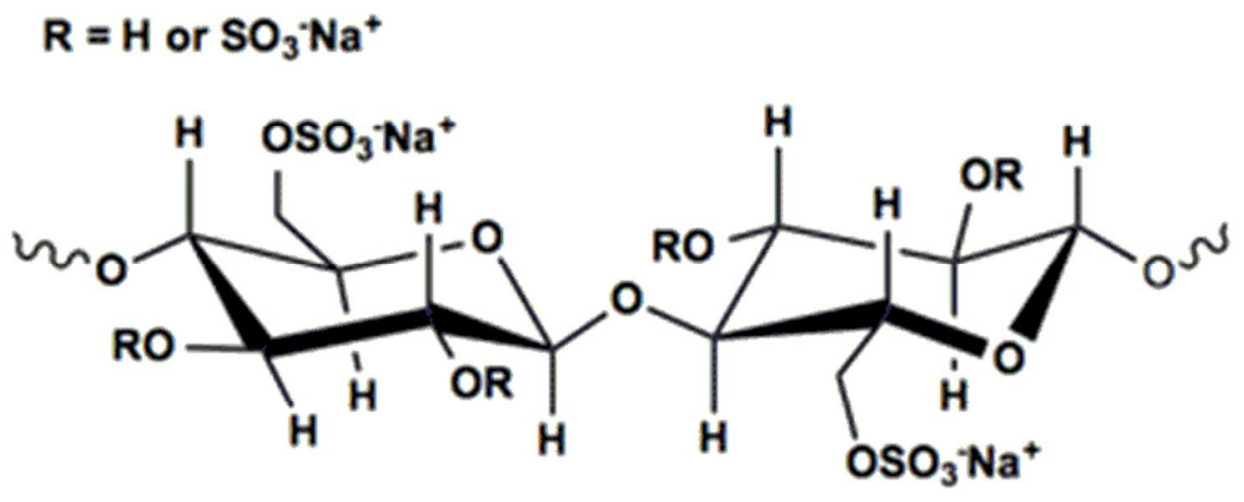

\section{Sodium Cellulose Sulfate}<smiles>CC(C)(C)NC(=NCl)NC(C)(C)C</smiles>

\section{Poly(methylene-co-guanidine)}

Figure 7. The chemical structures of sodium cellulose sulfate (CS) and poly(methylene-co-guanidine) hydrochloride (PMCG)

$81 \times 68 \mathrm{~mm}$ (300 x 300 DPI) 


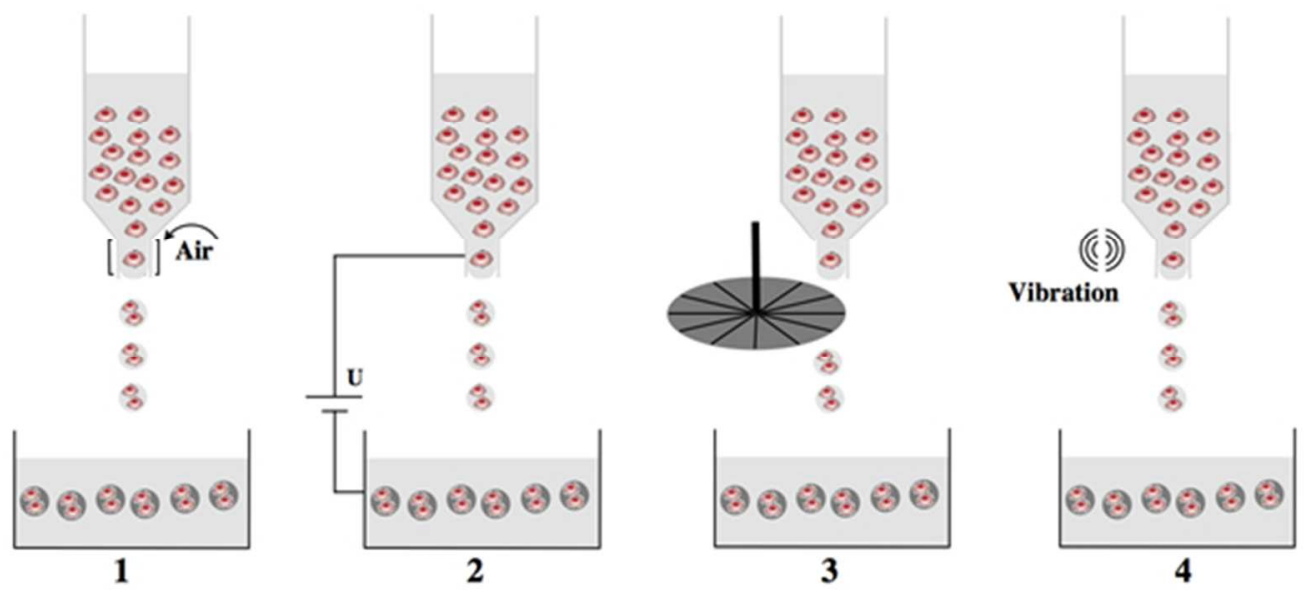

Figure 8. Formation of droplets by: coaxial air-flow (1), electrostatic potential (2), rotating disk (jet cutter) (3), and vibrating nozzle (4). Cells are finally entrapped in hydrogel microspheres after falling down in the gelation bath

$213 \times 96 \mathrm{~mm}(72 \times 72 \mathrm{DPI})$ 
2

3

4

5

6

7

8

9

10

11

12

13

14

15

16

17

18

19

20

21

22

23

24

25

26

27

28

29

30

31

32

33

34

35

36

37

38

39

40

41

42

43

44

45

46

47

48

49

50

51

52

53

54

55

56

57

58

59

60

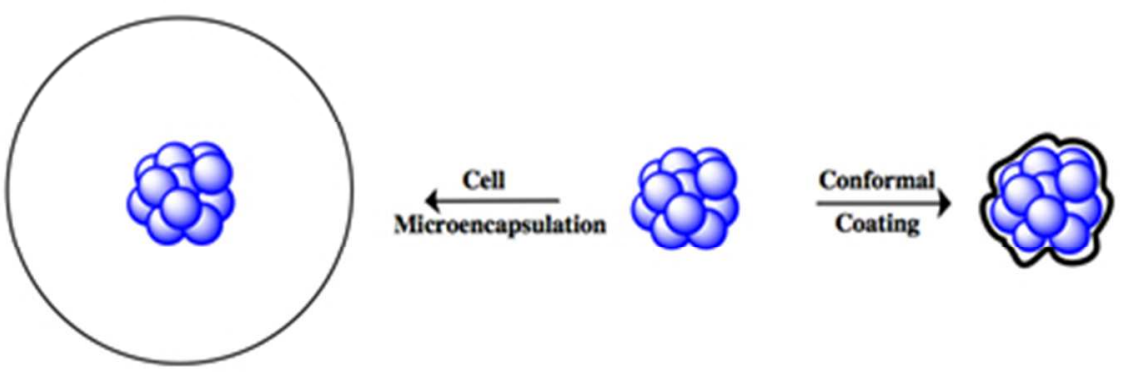

Figure 9. Comparison of conformal coating and cell microencapsulation $154 \times 50 \mathrm{~mm}(72 \times 72$ DPI $)$ 
Table 1. Selected alg-based physical hydrogels applied for cell microencapsulation

\begin{tabular}{|c|c|c|c|}
\hline $\begin{array}{c}\text { Divalent } \\
\text { ions }\end{array}$ & Cell type & Target & Reference \\
\hline $\mathrm{Ca}^{2+}$ & \begin{tabular}{|l|} 
BMSC $^{1}$ \\
Hepatocytes \\
Pig islets \\
ADSC $^{2}$ \\
CSP $^{3}$ \\
\end{tabular} & $\begin{array}{l}\text { Treatment of stress urinary incontinence } \\
\text { Development of bio-artificial liver } \\
\text { Impact of implantation sites on the biocompatibility } \\
\text { Study of angiogenic and osteogenic potential of ADSC } \\
\text { Therapeutic approach for cartilage regeneration }\end{array}$ & $\begin{array}{c}{[50]} \\
{[51]} \\
{[52]} \\
{[53,54]} \\
{[55]}\end{array}$ \\
\hline $\mathrm{Ba}^{2+}$ & \begin{tabular}{|l|} 
Rat islets \\
Neuroblastoma \\
WJMSC $^{4}$
\end{tabular} & $\begin{array}{l}\text { Study of islets function in vitro and in vivo } \\
\text { Cryopreservation of neurospheres by encapsulation } \\
\text { Optimized microencapsulation of MSC by vibrational nozzle }\end{array}$ & $\begin{array}{l}{[56]} \\
{[57]} \\
{[58]}\end{array}$ \\
\hline $\mathrm{Ba}^{2+} / \mathrm{Ca}^{2+}$ & $\begin{array}{l}\text { Human islets } \\
\text { ARPE- } 19^{5}\end{array}$ & $\begin{array}{l}\text { Viability and function after transplantation into diabetic mice. } \\
\text { In vitro study of encapsulated human retinal pigment epithelial cells }\end{array}$ & $\begin{array}{c}{[59,60]} \\
{[61]}\end{array}$ \\
\hline
\end{tabular}


Table 2. Examples of chemical hydrogels applied for cell immobilization

\begin{tabular}{|c|c|c|c|}
\hline Material & Preparation & Cell & Reference \\
\hline Alginate & $\begin{array}{l}\text { Click reaction with tetrazine-norbornene modified hydrogel } \\
\text { (no ionic cross-linkings) }\end{array}$ & $\begin{array}{l}\text { EGFP-expressing } 3 \mathrm{~T} 3 \\
\text { fibroblast }\end{array}$ & {$[140]$} \\
\hline \multirow{4}{*}{ PEG } & Thiol-ene reaction of PEG diacrylate with thiolated gelatin & Fibroblasts; keratinocytes & {$[141,142]$} \\
\hline & $\begin{array}{l}\text { Maleimide, acrylate and vinyl sulfone-modified PEG cross- } \\
\text { linked with peptides }\end{array}$ & $\mathrm{C} 2 \mathrm{C} 12$ myoblast & {$[143]$} \\
\hline & $\begin{array}{l}\text { Photo-polymerization of fibrinogen-g-PEGacryloyl and PEG } \\
\text { diacrylate }\end{array}$ & BMSC & {$[144]$} \\
\hline & Photo-polymerization of PEG diacrylate & Huh-7.5 & [145] \\
\hline \multirow{3}{*}{ Chitosan } & $\begin{array}{l}\text { Photo-polymerization of chitosan grafted with lactic acid and } \\
\text { methacrylate }\end{array}$ & \multirow{3}{*}{ Chondrocytes } & [146] \\
\hline & Chemically cross-linked chitosan hydrogel loaded with gelatin & & [147] \\
\hline & N-succinyl-chitosan gelation with aldehyde hyaluronic acid & & [148] \\
\hline \multirow{3}{*}{ Dextran } & Photo-polymerization of dextran with benzophenone & Osteoblast-endothelial cell & [149] \\
\hline & Gelation of methacrylate and lysine functionalized dextran & Smooth muscle cells & [150] \\
\hline & Photopolymerization of dextran-acrylate & Embryonic stem cells & [151] \\
\hline \multirow{4}{*}{ HA } & HA cross-linked via disulfide bond formation reaction & Fibroblasts, stem cells & [152] \\
\hline & Methacrylated HA cross-linked by UV exposure & MSC & [153] \\
\hline & Peroxidase catalyzed oxidation of tyramine-substituted HA & Chondrocytes & [154] \\
\hline & Conjugate addition of thiol-modified HA onto PEG diacrylate & Adipocyte-stem cells & [155] \\
\hline \multirow{2}{*}{ PVA } & UV photopolymerization & \multirow{2}{*}{ L929 fibroblast } & [156] \\
\hline & Click hydrogels formed by hydrazone bonds & & [157] \\
\hline
\end{tabular}


Table 3. Xenotransplantation of encapsulated cells in animal models

\begin{tabular}{|c|c|c|c|c|}
\hline $\begin{array}{c}\text { Transplanted } \\
\text { model }\end{array}$ & Cell type & Transplantation site & $\begin{array}{l}\text { Materials for } \\
\text { encapsulation }\end{array}$ & Reference \\
\hline \multirow{6}{*}{ Mice } & Neonatal porcine islets & Peritoneal cavity & Ca-alg and Ba-alg & $\begin{array}{l}{[273]} \\
{[274]}\end{array}$ \\
\hline & Rat islets & $\begin{array}{l}\text { Subcutaneous tissue } \\
\text { Intraperitoneal space } \\
\text { Peritoneal cavity } \\
\end{array}$ & $\begin{array}{l}\text { Agarose / poly (styrene } \\
\text { sulfonic acid) } \\
\text { Alg-PLL-PEG } \\
\text { Agarose } \\
\end{array}$ & $\begin{array}{l}{[283]} \\
{[80]} \\
{[187]} \\
\end{array}$ \\
\hline & Human islets & $\begin{array}{l}\text { Omental pouch } \\
\text { Peritoneal cavity }\end{array}$ & \begin{tabular}{|l|} 
Agarose \\
Ba-alg \\
\end{tabular} & $\begin{array}{l}{[279]} \\
{[300]}\end{array}$ \\
\hline & Neonatal pig hepatocytes & Abdominal cavity & Ba-alg & [295] \\
\hline & \begin{tabular}{|l|} 
Rat hepatocytes \\
Human hepatocytes \\
\end{tabular} & Peritoneal cavity & Alg-PLL-alg & {$[270,271]$} \\
\hline & Fish islets & Abdominal cavity & Ba-alg & [299] \\
\hline \multirow[b]{2}{*}{ Rat } & Pig islets & $\begin{array}{l}\text { Subcutaneous tissue } \\
\text { Abdominal cavity }\end{array}$ & $\begin{array}{l}\text { Ca-alg } \\
\text { Ba-alg }\end{array}$ & $\begin{array}{l}{[282]} \\
{[301]}\end{array}$ \\
\hline & Guinea pig hepatocytes & Peritoneal cavity & $\begin{array}{l}\text { acrylonitrile-sodium } \\
\text { methallyl-sulfonate } \\
\text { copolymer }\end{array}$ & {$[302]$} \\
\hline \multirow{2}{*}{$\begin{array}{l}\text { Non human } \\
\text { primates }\end{array}$} & \multirow{2}{*}{ Pig islets } & Intraportal injection & No material & $\begin{array}{l}{[288]} \\
{[293]}\end{array}$ \\
\hline & & Intraperitoneal space & Ca-alg-PLL & [303] \\
\hline
\end{tabular}

